\title{
Stones Alive!
}

\section{An Exploration of the Relationship between Humans and Stone in Southeast Asia}

\author{
Monica Janowski \\ School of Oriental and African Studies, University of London \\ monica.janowski@gmail.com
}

\begin{abstract}
This article explores the significance of stone in Southeast Asia, arguing that within the animistic ontologies of the region stone is a central cosmological concept. Stone, for the people of this region, is a locus of sentience, expressed through the presence of spirits. Cosmic power, which is equivalent to vital force, is believed to flow through the cosmos, flowing fastest in water and coalescing in stone. Stone is a source of power and life and is associated with origins and ancestors; the placing of stone is associated with status and becoming a significant ancestor. Southeast Asian ontologies, which regard the material world as made up of a constant flow of cosmic power, closely identified with life itself, do not separate mind and matter and see stone as alive. Stone is a lens through which we can view these ontologies and perhaps even question our own.
\end{abstract}

\section{Keywords}

stone - power - life - beliefs - mountains - landscape - water - animism

Tuked Rini pulled out his whetstone and used it to prop open the Spirit Tiger Rock's mouth. This illuminated the inside. They peered in and spotted some people in there. So they all entered the Hugely Tall and Powerful Spirit Tiger Rock's mouth with war in mind.

JANOWSKI 2014/2016:56 
Semangat (Spirit of Life) is not limited to animals. It permeates the universe, dwelling in man, beast, plant and rock. The universe teems with life: the life of a fire is swift and soon burns out, a rock's life is slow, long and dreamlike.

LADERMAN 1991:41

The first quote above is from the legend of Tuked Rini, a culture hero from the Kelabit Highlands in Sarawak. He is pictured in Figure 1, shimmering with cosmic power or life force, whose omnipresence-including in stone-within the animistic cosmologies of the region is emphasized in the second quote. The 'Hugely Tall and Powerful Spirit Tiger Rock' into which/whom Tuked Rini enters embodies the presence of life in stone and its sentience (Janowski 2014:52).

During my years of fieldwork in the Kelabit Highlands, I could not fail to be alerted to the cosmological significance of stone. There is a very long history of stone-moving in the Kelabit Highlands, which includes the creation of huge mounds of river-rolled stones and the building of walls. ${ }^{1}$ This is part of a broader practice of making 'marks' (etuu) on the landscape (Janowski and Langub 2011), which is associated with feasting and status. Until the 195os, the people of the highlands commemorated the dead with large stones and placed their dead close to stone jars and dolmens in forest cemeteries (Figure 2). The Kelabit regard natural features of the landscape as petrified houses; they used to collect pub (charms) including 'thunderstones' and other unusual stones found in the forest (Janowski and Barton 2012) (Figure 3), and until the 1970s shamans kept spirit-inhabited small stones that did their bidding in return for blood meals (Janowski 2016). ${ }^{2}$

I suggest that the Kelabit exemplify ways of relating to stone that are widespread in Southeast Asia, ways that I will explore here. There are good grounds for understanding the cosmological beliefs that underlie stone-related

1 Barker et al. 2009; Barker et al. 2008; Lloyd-Smith et al. 2013; Lloyd-Smith et al. 2010.

2 The question of why spirits should require blood meals is a fascinating one, to which I do not at present know the answer. Perhaps this is linked to the association, at least among the Kelabit, between spirits and the colour red-it is said to be the only colour that they can see. 


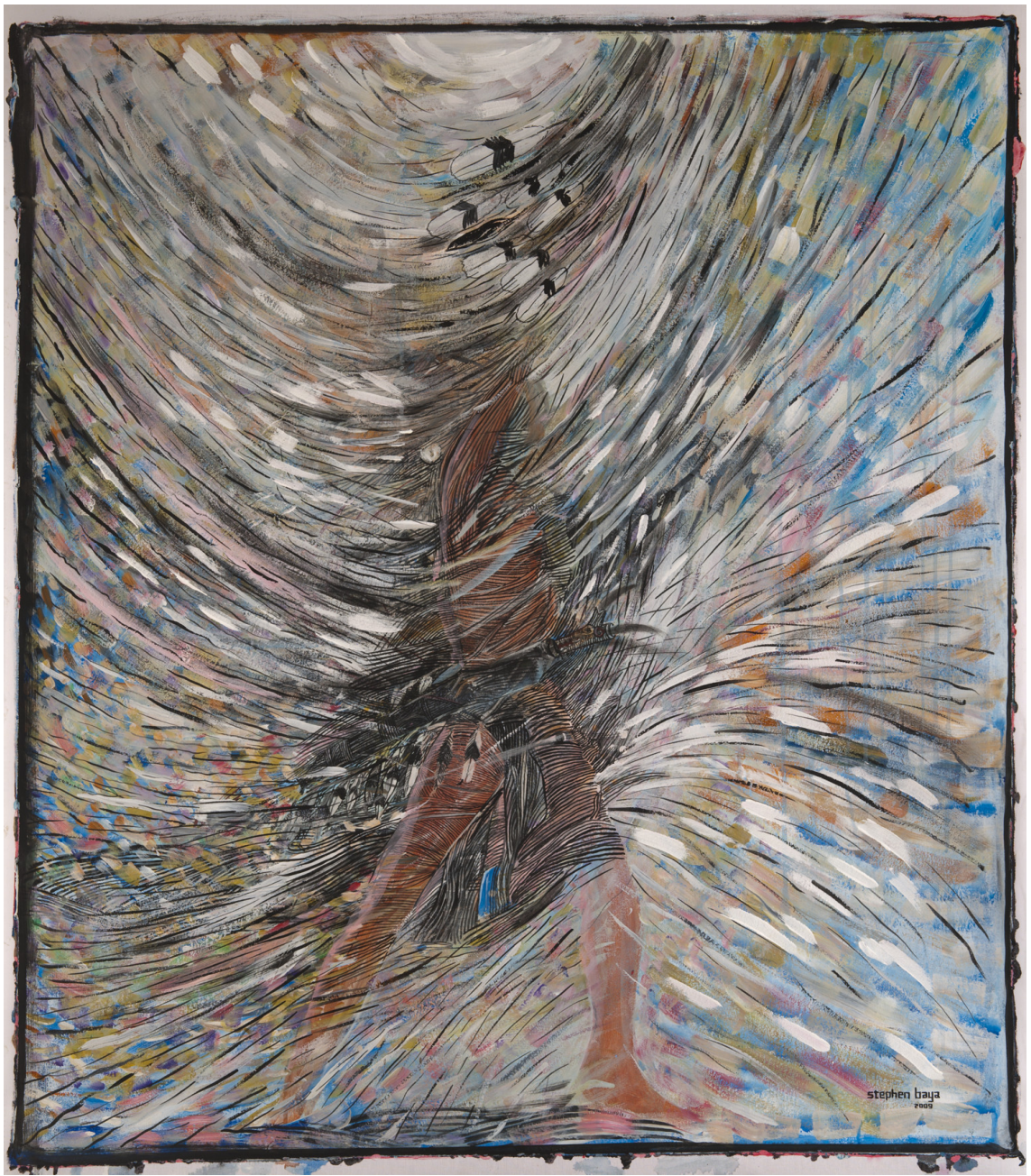

FIGURE 1 The Kelabit culture hero Tuked Rini shimmering with vital force/cosmic power (lalud)

PAINTING BY KELABIT ARTIST STEPHEN BAYA, 2009

behaviours and beliefs in Austronesian-speaking societies of Southeast Asia in the same frame of reference, as attested through the many publications from the Comparative Austronesian Project under the leadership of James Fox at the Australian National University, and as is the basis of the 'field of ethnological study' put forward by De Josselin de Jong (1980, 1984). Given the long-standing interactions which Southeast Asia has had with neighbouring parts of the world through migration, maritime trade, cultural contact and political ties, it is, I believe, useful to look at stone-related beliefs over a wider area, whether or 


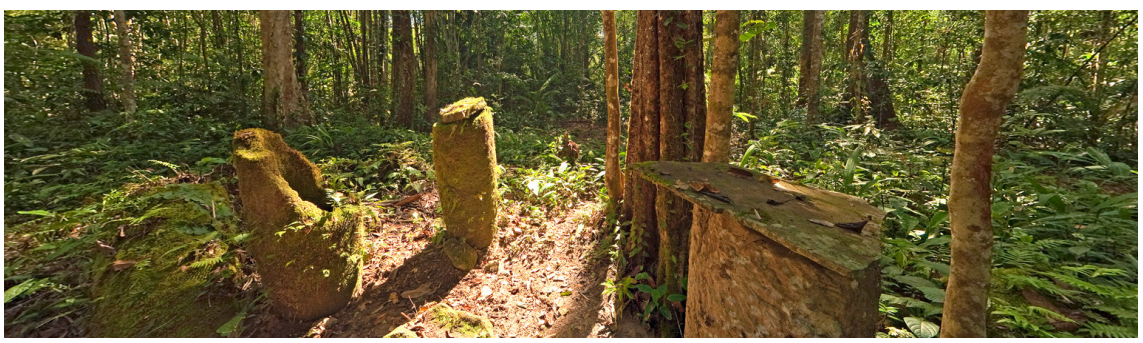

FIGURE 2 Long Diit megalithic cemetery, Kelabit Highlands, Sarawak, with stone jars and stone cists

PHOTO BY DOUGLAS CAPE, 2009

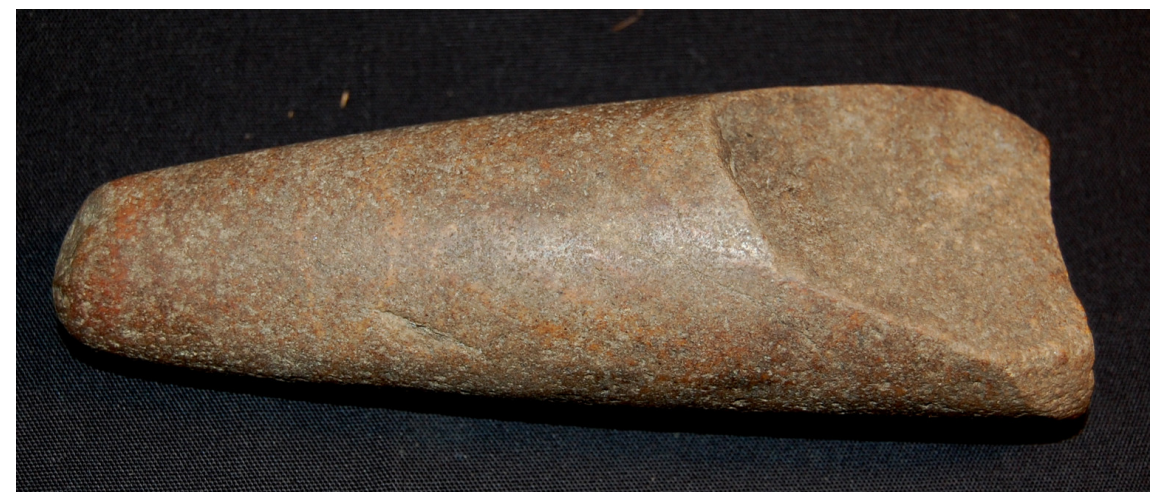

FIgURE 3 A 'thunderstone' (batu pera'it) from the Kelabit Highlands. Accession number 1988 as 22, British Museum collection COLLECTED BY AUTHOR, 1987. PHOTO BRITISH MUSEUM, 2008

not the inhabitants of the places concerned are Austronesian-language speakers. I will also make some reference to beliefs in Polynesia, Taiwan, Madagascar, Japan, New Guinea, and China as these relate to stone.

My argument in this article relates to recent academic debates around matter, materiality, objects, and things; I will conclude with some thoughts on these.

The ways in which people in Southeast Asia relate to stone reflect the way in which they conceive of the natural environment and the broader cosmos, and to their ontology - their sense of the nature of reality. This ontology is grounded in belief in a cosmic power or vital force that flows through the cosmos 
(Fox 1980). Belief in an all-pervading vital force is fundamental in the region. As Kaj Arhem (2016a) has pointed out, this belief connects the peoples of upland and lowland, mainland and insular Southeast Asia. The significance of belief in a vital force was recognized in early ethnographies of insular Southeast Asia, such as Skeat and Blagden's book on Malay magic (1900) and Kruyt's book on animism (1906), as well as by researchers working more recently in both mainland and island Southeast Asia. ${ }^{3}$ In Malay this force is described as semangat, which Winstedt (1956:19) glosses as 'vital or effective force' and Laderman (1991:41-2) glosses as 'Spirit of Life'. Among the Luwu (in Sulawesi) the cognate term is sumangé, which Errington (1989) glosses as 'potency'. Among the Wana of Sulawesi it is described as baraka, which is an Arabic term referring to divine power (Atkinson 1989). Among the Ao Naga it is described as aren (Mills 1926:112). In Javanese it is described as kasektèn, which Anderson (1972) glosses as 'power' or 'primordial essence'. In Balinese it is called sekti, which Geertz (1980:106) glosses as 'divinely inspired gift or power'. Geertz has argued that Balinese sekti may be equated with the Polynesian concept of mana (Geertz 1980:106). Barbier (1999:86) has argued that the Batak notion of sahala is also equivalent to mana. The Kelabit of Sarawak call it lalud. I have previously addressed the implications of belief in such a force. ${ }^{4}$ Belief in a vital force that drives the cosmos extends both east and west from Southeast Asia. Kasektèn and sekti both derive from the Sanskrit šakti, which refers to the energy or active part of a deity. There also seem to be plausible links between beliefs in vital force in Southeast Asia and beliefs in ch'i/chi/qi within Chinese Taoism (see, for instance, Shaw 1988:92-3) and musubi within Japanese Shintoism (see, for instance, Hirai 1960:42).

Belief in such a vital force or cosmic power coursing through the cosmos is part of a knowledge system and ontology that does not separate biology from physics; the lack of any separation means that vital force cannot be separated conceptually from cosmic power. There is, in this type of ontology, only one dynamic in the cosmos, and one fundamental force flowing through it. While this is manifested differently in different contexts, there is no essential difference between the force that drives volcanoes and that which animates a human being (Janowski 2016). Such an ontology may be described as animistic. There has been a resurgence in interest in examining animism within anthropology

3 Benjamin 1979; Endicott 1970; Fox 1987; Kirsch 1973.

4 Janowski 1984, 1995, 2003a, 2003b, 2007a, 2007b, 2012, 2014a, 2016; Janowski and Kerlogue 2007; Janowski and Langub 2011. Although Needham (1976) has argued against any belief in such a life force in Southeast Asia, this is on the (in my view, mistaken) basis that such a belief would necessarily be grounded in a 'Western'-style notion of causality. 
in the past couple of decades (Descola 2013 [2005]; Viveiros de Castro 1998), including in Southeast Asia (Allerton 2009; Sprenger and Arhem 2016).

An animistic ontology is not confined to those peoples in the region who practise 'tribal' religions; it is also part of the belief systems of those who practise world religions - Islam, Christianity, or Buddhism - even though animistic beliefs and practices may be viewed in a negative light by those religions. Across boundaries between peoples holding to different world religions and those who are not yet 'converted' there are common ontological threads, rooted in belief in that vital force, which is regarded as the fundamental dynamic of the cosmos.

\section{Flow and Accumulation of Vital Force: Sentience and Spirits}

While Southeast Asians believe that vital force is present everywhere-is 'immanent' (Fox 1987:524) or omnipresent in the universe-they do not see it as present everywhere to the same degree. In its 'flow' through the cosmos (Fox 1980) it accumulates in certain places, which we may call 'hot spots'. Such hot spots of vital force are associated with the presence of spirits - an English gloss for many different terms in different Southeast Asian languages, used to refer to self-aware, independently-acting beings. They are, as it were, the sentient expression of free-flowing vital force. Sentience appears to be a characteristic, perhaps even a defining characteristic, of a hot spot of vital force.

Many spirits are associated with, or inhabit, a material body. Not all material bodies are associated with, or inhabited by, a spirit, however; and if the entire material world is imbued with vital force, this means that the free-flowing vital force coursing through all matter does not always cohere into sentient spirits. It would appear that as vital force accumulates, it is believed to eventually develop sentience. It is then associated with—or perhaps it 'becomes'-a spirit. It seems possible that all matter, through its 'aliveness', is regarded as possessing some level of sentience; and that at a certain point this becomes so clearly evident that humans begin to interact with it as a sentient spirit. Or it may be that the coming into being of a spirit is regarded as being an event in time rather than something gradual. It would appear, however, that spirits can be stronger or weaker, suggesting that the process of their formation is gradual.

While the entire landscape is imbued with vital force, there are certain people, animals, plants, places, and objects within it who/which are regarded as being particular accumulations of power and vital force. The presence of powerful spirits in these spots is discerned definitively through observation, including of unusual events and the success of offerings. Most such places are associated with water and stone: deep pools in rivers; localized bodies of water, 
particularly deep pools and especially those on top of mountains; whirlpools in the sea; waterfalls; isolated natural boulders; cliffs; and stony mountain-tops.

\section{Stone, Water and the Flow of Vital Force}

Stone and water are both particularly significant substances cosmologically and ontologically in this region (as indeed they are elsewhere in the world). This is almost certainly because they lie at the ends of a continuum between soft/wet and hard/dry, a continuum which is, I would suggest, central to beliefs about the flow of vital force through the cosmos. The logic of the significance of water is that vital force flows faster and more vigorously through wet, soft substances; and water is therefore the substance through which vital force flows most effectively. Hard, dry substances, and particularly stone, at the other end of the continuum, are places where vital force slows down and eventually (almost) stops moving altogether. Stone, then, is an accumulation, a reservoir of vital force.

Fast movement of vital force is a characteristic of youth; slow movement of vital force, as well as its accumulation, is associated with age. This is why older trees are believed to be the locus of spirits, leading to a fear of felling big trees, because the spirits inhabiting them object to this (K. Arhem 2016b:296; N. Arhem 2016:134; Janowski 2016:193-4). Eventually, it is believed that trees may turn to stone; this is believed to have happened in the case of a tree called bolitus, which is in the grounds of the Sabah Museum (Phelan 1997:79). Vital force moves more slowly, and accumulates, in older humans, too. When they die, they become, eventually, dry bones - and come to be closely associated with stone (see below).

Physical houses also express this belief in the accumulation and hardening of vital force with age and status (Bloch 1995). The houses of high-status leaders are inhabited over generations and are-or were, traditionally, before the advent of modern materials and tools led to more durable materials becoming more easily available to all — built of harder and more durable materials (hardwood rather than bamboo and leaves) than the houses of other people. Stone is also more likely to be present in traditional higher-status houses. Traditionally, houses are almost always built on piles in the region, usually with stones around the base of the piles. High status in the region means a closer link with the ancestors, and high-status families often inhabit long-lived ${ }^{5}$ houses

5 Houses in the region are believed to be alive, as denoted by the title of Waterson's book The Living House (Waterson 1991). 
believed to have been established by supernatural ancestors (Waterson 1991). High-status, long-lived houses associated with a long and high-status ancestral line are believed to be associated with, and sometimes inhabited by, ancestral spirits (Waterson 1993). There is a sense in which such houses are themselves regarded as conscious and sentient, through the spirits inhabiting them and probably also the vitality contained in the wood of which they are made and the process of their construction (Waterson 2003). Certain parts of the house-the hearth and the central post-are regarded as particularly strongly associated with ancestral spirits. The hardening of ancestral houses, eventually becoming stone, is expressed in the fact that stones in the landscape may be regarded as parts of the houses of significant ancestors (see, for instance, Jenks 1911:200, 202).

Water, at the other end of the continuum, is widely believed to be inhabited by water spirits, which derive from the Indian naga and the Chinese lung as well as from Austronesian and Melanesian beliefs. Such water spirits are powerful, sometimes protective, and are sometimes monitors of correct behaviour vis-àvis the natural environment, causing rain and floods which can be life-giving or destructive. ${ }^{6}$ In my recent research into beliefs about dragons and spirit snakes in Sarawak I have found that there are strong indications that water is not only inhabited by such spirits but is identified with them. Dragons and spirit snakes can, I would suggest, be regarded as expressing what one might describe as the entified sentience of water itself.

\section{$4 \quad$ Spirits in Stone and the Human Relationship with Them}

Like animals, stone is arguably 'good to think with' (Lévi-Strauss 1973 [1962]); this is particularly true in the tropics, where it is striking in its permanence in a context where everything else decays rapidly. Many of the entities that are not biologically alive but are locally regarded as sentient and possessing spirits are stones. Such stones are believed to be alive and are often believed to grow, as are, for example, the batu idup in Sabah (Phelan 1997:59, 73-9) (see Figure 4) and as are stones in Tana Toraja in Sulawesi (Waterson 2009). To live forever is expressed in the Toraja language as tuo batu, 'to live like a stone' (Waterson 2009:131). ${ }^{7}$ Stones regarded as being alive may be of any size, ranging from huge

6 Janowski 2018, forthcoming-b; Ngaosrivathana 2009; Stuart-Fox and Misai 2010; Terwiel 1985.

7 Mus (1933:376) suggested that the belief in stones that grow might be due to the proximity of a tree; he seemed to be suggesting that the belief might be that growing stones are extrusions of the life of a tree. However, I would suggest rather that stone itself may actually be seen as alive, without the need for it to be 'grown' by a tree. 


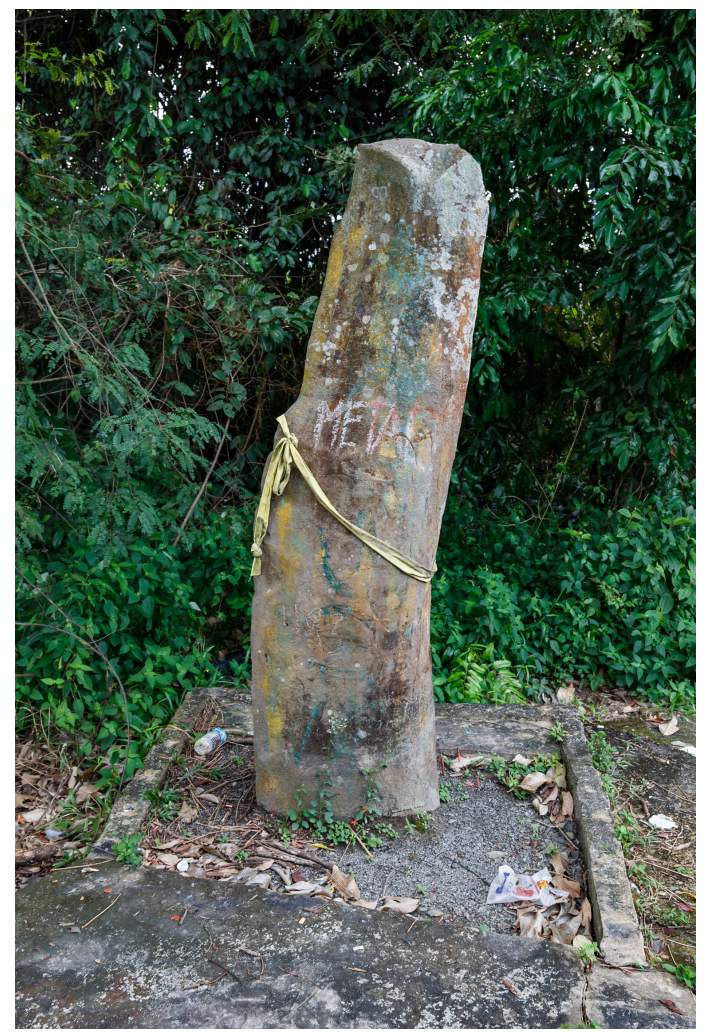

\section{FIGURE 4}

Batu tumbu/batu idup ('living stone') in Kimanis, Sabah PHOTO BY UWE ARANAS, 2013. HTTPS://COMMONS.WIKIMEDIA .ORG/WIKI/FILE:KIMANIS _SABAH_BATU-TUMBUH-01.JPG \#/MEDIA/FILE:KIMANIS_SABAH _BATU-TUMBUH-01.JPG.

boulders to small, portable stones. Humans in the region have a range of relationships with the spirits in these stones.

In many places in insular and mainland Southeast Asia, as well as on many Polynesian islands, there are large stones associated with places; their resident spirits may be regarded as 'lords' of the land (Mus 1933). Such spirits are not infrequently also regarded as guardian spirits for local humans, so long as appropriate offerings are made to them, and they are the objects of sacrifice and veneration. They are often associated with sacred groves, which may contain stones brought there as part of rituals carried out when a village is founded (Domenig 2014:58, 60, 65). Such spirits are, sometimes implicitly and sometimes explicitly, regarded as being in some sense ancestral to humans, as is the case in Singkawang in Kalimantan, where both Chinese and Dayaks make offerings to penunggu, which are local earth deities but are addressed using terms which mean 'grandfather' (Chai 2017) (see Figure 5). Other stones believed to be the residence of guardian spirits are the pangantoho stones of the Olo Ngadju of Borneo, to which heads and blood were brought after head-hunting (Kruyt 1906:219). The Kenyah of Borneo used to keep 'holy' stones within which 


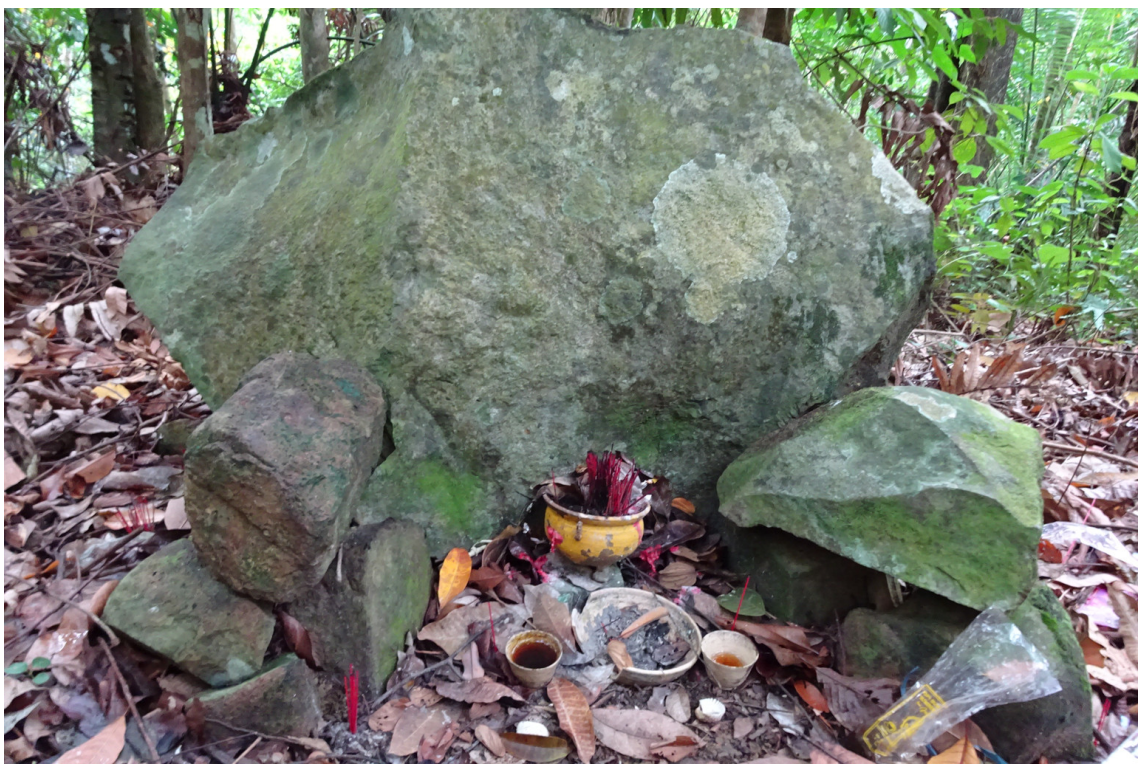

FIGURE 5 A pekong stone inhabited by a penunggu spirit of place, on Gunung Sari near Singkawang in Indonesia, with offerings in front of it PHOTO BY ELENA CHAI, 2017

guardian spirits were said to reside (Hose and McDougall 1912, 2:16). In Sabah, tingolig stones are said to protect villages and to be inhabited by guardian spirits (Phelan 1997: Chapter 3). In Nias, 'holy' adu stones have been regarded as the abodes of guardian spirits (Feldman 1990:24; Kruyt 1906:209). The stone images at Gintu, Bulili and elsewhere in central Sulawesi, and the stone images erected at the entrance to the harbour in Kai Tanimbar, were in the early twentieth century regarded as the residences of guardian spirits (Perry 1918:64).

Small stones are also believed to house spirits. Among the Kelabit, as well as among other peoples in Sarawak, I have come across instances of people collecting and keeping small stones that are oddly shaped or coloured, particularly if they are perfect and unbroken. Such stones may, it is believed, be inhabited by spirits. In Belu in Timor, stones which have cylindrical or elliptical forms or are shaped like the human body are believed to house spirits (Perry 1918:57). Among the Batak, oddly shaped stones are described as pagar or pangulubalang and are regarded as housing spirits (Barbier 1999:13). In Indonesia and Malaysia, stones and hard objects with unusual characteristics, known as mustika or buntat, are kept as charms or amulets, and are believed to protect their owners; these can even be bought online. They are considered to possess vital force and it is probable that all are considered to be inhabited by a spirit. They are believed to originate from many sources, including various animals, 


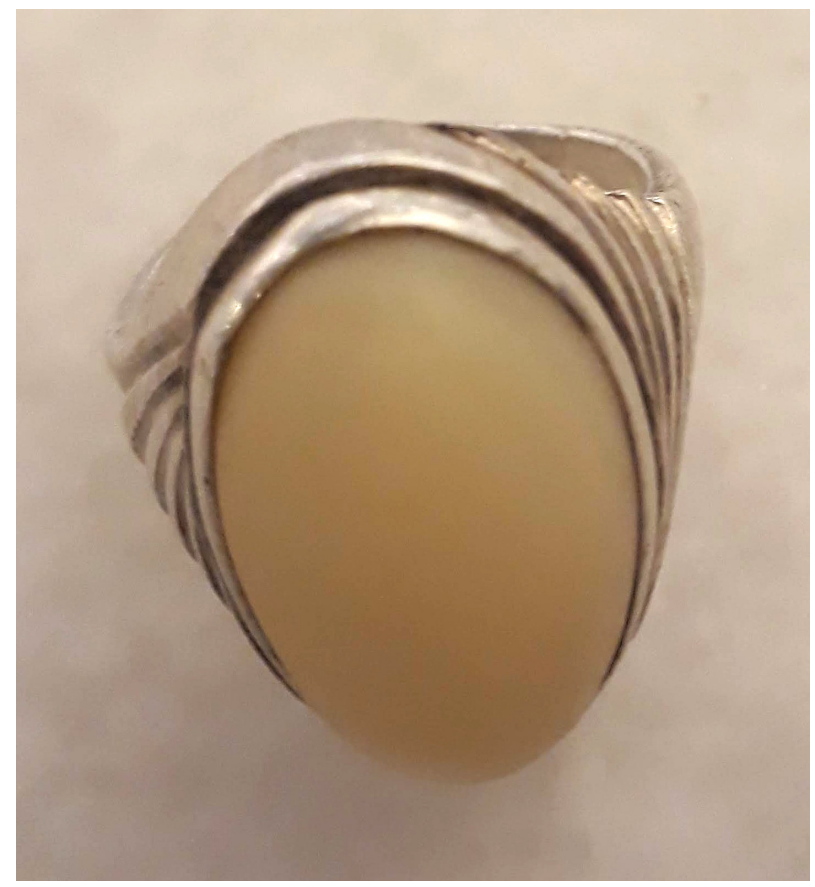

FIGURE 6

Ring with stone said to have come from the head of a python COLLECTED BY JOHN WALKER. PHOTO BY AUTHOR, 2019

coconuts, and dew. There is a widespread belief in Sarawak that pythons sometimes 'offer' such stones, which they carry on their heads, to certain people, and that these, if kept, will transmit their vital force to those individuals and make them successful ${ }^{8}$ (see Figure 6). Among the Dani in New Guinea, stones which are particularly smooth, round, have an unusual shape or colour, are fossils, or are natural quartz crystals may be regarded as being imbued with wusa or 'supernatural power'; these are kept in cabinets called ganekhe and are a source of power for their owners (Hampton 1999:125).

Small stones laden with vital force and inhabited by spirits are kept by shamans and magicians. In the Kelabit Highlands, our neighbour Balang Pelaba had, in his youth, been a dayong or shaman, and he told me that he had had a number of stones of different colours which were inhabited by spirits ( $a d a^{\prime}$ ) that gave him power (lalud). The spirits in such stones have to be fed blood, or they will turn on their owners and take their blood.

A large proportion of the stones that are believed to carry vital force and are kept as amulets in Southeast Asia are ancient stone tools-adzes, axes, and sago pounders — although they are not recognized as such locally but are

8 Personal communication, Jayl Langub, 2017 and 2018. Jayl has told me a number of stories about encounters with such pythons. 
widely believed to be 'thunderstones' which have fallen from the sky. ${ }^{9}$ Those kept by the Kelabit (see Figure 3) are ancient sago pounders (Janowski and Barton 2012). Sago is now processed effectively using wooden and bamboo implements in Borneo; however, in the past it appears that it was processed using these very carefully crafted stone tools, as it still is in New Guinea (Gonthier 1987). The pounders currently used in New Guinea are, in fact, identical to those which were, until recently, kept as 'thunderstones' by the Kelabit. It is very probable that the reason for using these beautifully crafted stones to pound sago reflects the belief that these stones are important vehicles for vital force and perhaps a spirit.

The possibility of the transmission of vital force from stone is the basis for the practice of placing small stones believed to be full of vital force in contact with rice, something that is common in the region. Rice is, of course, the focal starch food, the centrepiece of meals, associated with high status and central to kinship and social structure (Janowski and Kerlogue 2007), and it is vital that it should thrive. In the Kelabit Highlands, 'thunderstones' carrying vital force were, until recently, placed in rice granaries, where they were believed to increase the amount of rice in the granary (Janowski and Barton 2012) (see Figure 3). There are similar beliefs elsewhere in Borneo (see, for instance, Sillander 2016). In Sabah, stones called bambarayon, selected from the river by an elderly person, are placed on top of rice granaries (Phelan 1997:102). The word bambarayon actually means 'rice-spirit', and in the past the stones were believed to be inhabited by the rice-spirit. Phelan also argues that the widespread presence of menhirs in rice fields in Tambunan in Sabah, $600 \mathrm{~m}$ above sea level, as well as on the coastal plain around Putatan, Penamang, and Kinarut, is grounded in the belief that this will increase the amount of rice in the field (Phelan 1997:93, 101 ).

It is worth noting, in the context of the belief on the part of Chinese in Southeast Asia that stones carry vital force and may house spirits (see, for instance, Chai 2017:16-21), that the belief that stone accumulates vital force which can be tapped or manipulated by humans is also present in mainland Chinese culture. When I was visiting a friend teaching at the university in Yantai in China in 2014, I was told that a large boulder had been transported (facilitated by a huge bribe) from a nearby sacred mountain and placed near the entrance to the campus to ensure the prosperity of the university. ${ }^{10}$ In China there is also a belief that placing large stones at key spots in the landscape has an influence

10 Jane Chesters, personal communication, 2014. 
on the flow of vital force. When I was in Yantai I was told by locals that large stones are always placed between the junctions of the roads at crossroads to prevent accidents, and I was shown many instances of this. Boulders are often placed at junctions in Sarawak too, and the placing of these may derive from similar beliefs; this would, I believe, be worthy of further investigation.

\section{5}

\section{Stone and the Ancestors}

Many spirits inhabiting large stones, including some of those which are 'guardian' spirits, are believed to be ancestral spirits or the spirits of culture heroes or semi-spirit ancestors who are considered to be the generic ancestors, and sometimes the founders, of a community or a wider group of people." ${ }^{11}$ Such stones, and the spirits within them, received, and in some places still receive, offerings of food and/or blood (Barbier 1999:139). Ancestors are regarded as a reservoir of vital force for their descendants, either through the group of unnamed ancestors or through certain powerful leaders in life, whose spirits remain separate from the communal spirit group after death. Ancestors continue in some sense to be present, giving their blessings to their descendants through the ancestral stones in which they are believed to be present. In Eastern Indonesia this is expressed very directly through the presence of stone graves of ancestors in the middle of villages or actually attached to the houses of the living, and through offerings made on stones associated with the graves (Figure 7).

Long-ago and founding ancestors are significant for the entire community, and stones associated with them are the focus of communal attention. Mao and Maikel Naga villages have large ancestral stones to which human heads taken on raids on other villages used to be shown (Hodson 1911:187, 189). The Garo erected menhirs at the entrances to their villages, with those near one village being regarded as the founding brothers, Chokki and Dalmang, while the smaller stones round about were regarded as their wives and children (Playfair 1909:82, 96-7). The Angami Naga had stones that Hutton interpreted as being the dwelling places of the spirits of the dead (Hutton 1926). In Timorlaut the ghosts of 'heroes' were venerated, and one was said to live in a stone outside the village of Mlutu (Hutton 1926:58). Among the Batak of Sumatra ancestral statues are carved (Figure 8). Some of these are on mounts, described as singa,

11 Founders of communities are extremely significant cosmologically in the region (Tannenbaum and Kammerer 2003). 


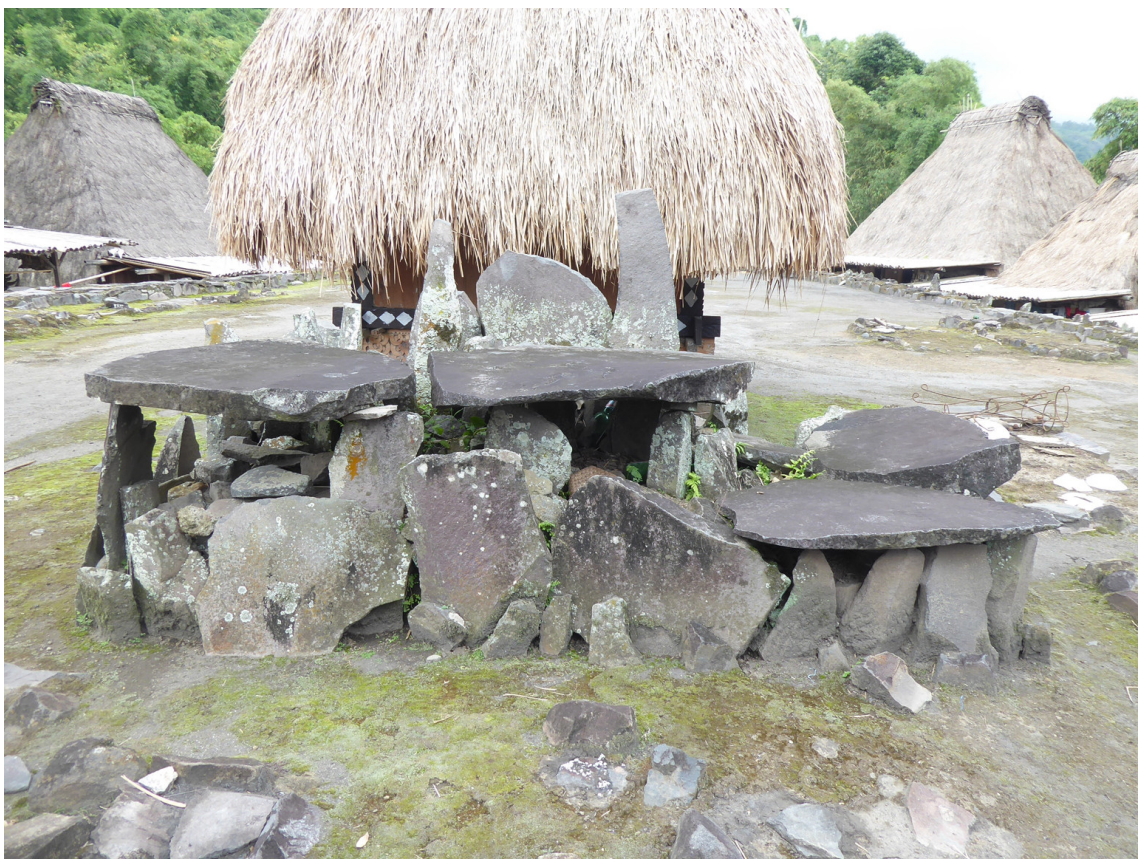

FIGURE 7 Pair of stones for offerings to male and female apical ancestors placed in association with the graves of significant ancestors, Bena village, Flores Pното BY AUTHOR, 2019

literally 'lion', a term used to refer (possibly obliquely, because of the danger of referring directly to the naga) to the underground/underwater spirit naga (Barbier 1999:107-13). The stone moai of Easter Island, which are carved with human-like heads, are also ancestral figures (see Figure 9).

Ancestral spirits may also live in small stones. In Lombok there are two important sacred places in the Bayan region, known as gedeng lauq (by the sea) and gedeng daya (on a mountain top), containing a great number of stones of different sizes, all shaped like lingga (see below for a discussion of the significance of lingga). These sacred places are believed to be inhabited by ancestors and to have 'magical' powers. The number of stones is believed to vary depending on conditions in the world. They are believed to be able to move to places where there is conflict and war, where they take the shape of human beings to guide and lead people into peace and order (Cederroth 2016:250-1). In the Timor region, too, ancestral spirits were, in the past, believed to live in small stones: on the island of Wetar near Timor, where there are immigrants from Timor, they kept stones called sirui, housing the spirits of ancestors brought from Timor (Perry 1918:57, 62). In the early twentieth century in Belu in central Timor, in East Timor, and on the islands of Luang and Sermata, travellers 


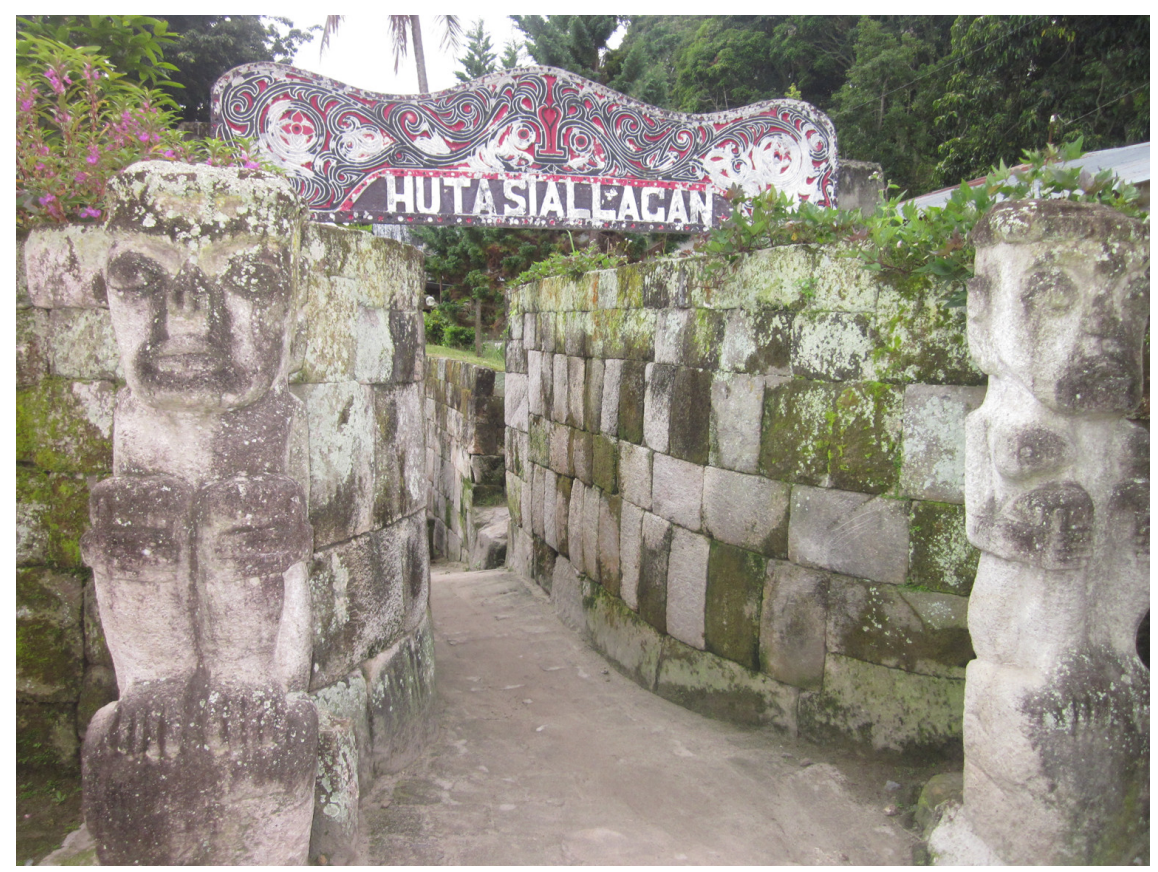

FIGURE 8 Stone ancestor figures at Huta Siallagan Batak village on Samosir Island in Lake Toba, Sumatra PHOTO AHANPRANATA, 2011. HTTPS:/COMMONS.WIKIMEDIA.ORG/WIKI/ FILE:HUTA_SIALLAGAN_BATAK_VILLAGE.JPG

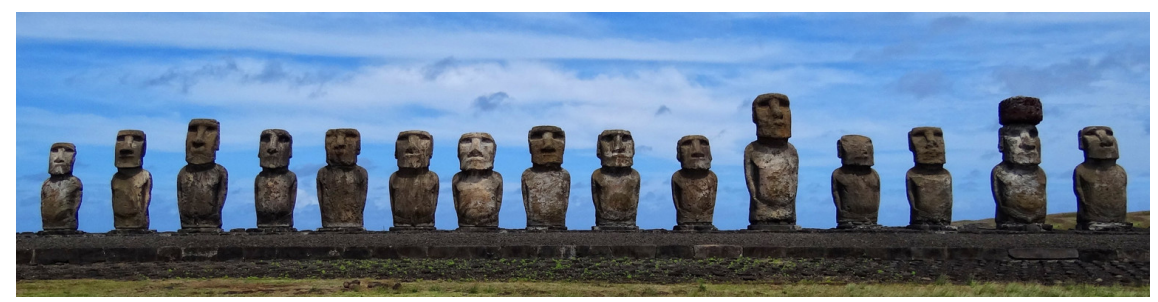

FIGURE 9 Ahu Tongariki moai statues PHOTO BY BJORN CHRISTIAN TORRISSEN, NO YEAR. HTTPS://COMMONS .WIKIMEDIA.ORG/WIKI/FILE:STANDING_MOAI_AT_AHU_TONGARIKI,_EASTER _ISLAND,_PACIFIC_OCEAN.JPG

carried small pieces of stone in which the spirits of the ancestors were said to live (Perry 1918:57). In the Leti group of islands the spirits of dead ancestors were also said to live in small stones, which were kept in the lofts of old houses; these stones were taken from graves eight days after a funeral (Perry 1918:57). In Sabah small guardian stones, probably believed to be inhabited by ancestral spirits, hang from the rafters in houses (Phelan 1997: Chapter 3). 
All ancestors are associated with origins, and this is the logic behind their being regarded as a source of vital force. There is a particularly strong association between founding ancestors and stone; founders are closest to mythological origins and the source of vital force itself. In the early twentieth century, each of the Aong villages of Tontemboan in Minahasa had a sacred stone that had a name and a personality, and to which offerings were made. The first job of anyone wanting to found a new settlement was to select a place for this stone (Perry 1918:63). In northern Nias a man who wanted to found a new village first erected a stone (Viaro and Ziegler 1999). In Sumba there are carved stone figures which are said to be the founders of the villages in which they are situated, and each village has a tree with an erect stone next to it, which is addressed as 'Elder Spirit' and to which prayers, invocations, and offerings are made (Hoskins 1999).

Ancestral spirits may be introduced into stones; Hampton describes how, among the Dani of Papua, wusa (vital force) and ancestral guardian spirits are channelled into ganekhe stones through rituals conducted in power-laden places (Hampton 1999:104, 125-7). Guardian stones housing ancestral spirits sometimes also had those spirits introduced through ritual. The introduction of spirits into stones requires high levels of vital force; among the Batak of Sumatra the carving is done, together with the introduction of spirits into the stones, by a datu panggana (magician-carver) who has high levels of sahala, or vital force (Barbier 1999:88).

The introduction of spirits into stones by humans is a way of managing and manipulating the vital force in stone. Once a spirit is present in a stone, humans can relate to that spirit as a sentient entity and benefit from the relationship. This is particularly true where the spirit concerned is an ancestor spirit. The carving of the stone with human features which often accompanies the introduction of ancestral spirits may perhaps be seen as a means of facilitating the introduction of those spirits into a stone; many of the guardian stones placed near villages have human features. The carvings of spread-eagled human figures which are found in many parts of insular Southeast Asia (see Figure 10), known as manusia kangkang in Indonesian, may also have been intended to introduce an ancestral spirit into a stone; this motif has also been used in Eastern Indonesian textiles, perhaps with the same function in that context. While the material relationship between an ancestral spirit and a stone is often not specified, stones housing ancestral spirits may be regarded as having heads and body parts, as actually 'being' the body of the ancestor; thus, in New Guinea ganekhe stones must be kept upright and comfortable, or they will cause earthquakes (Hampton 1999:160).

Ancestral figures may also be made of wood. In Central Nias wooden $a d u$ represent house ancestors and are kept within the house, while stone adu 


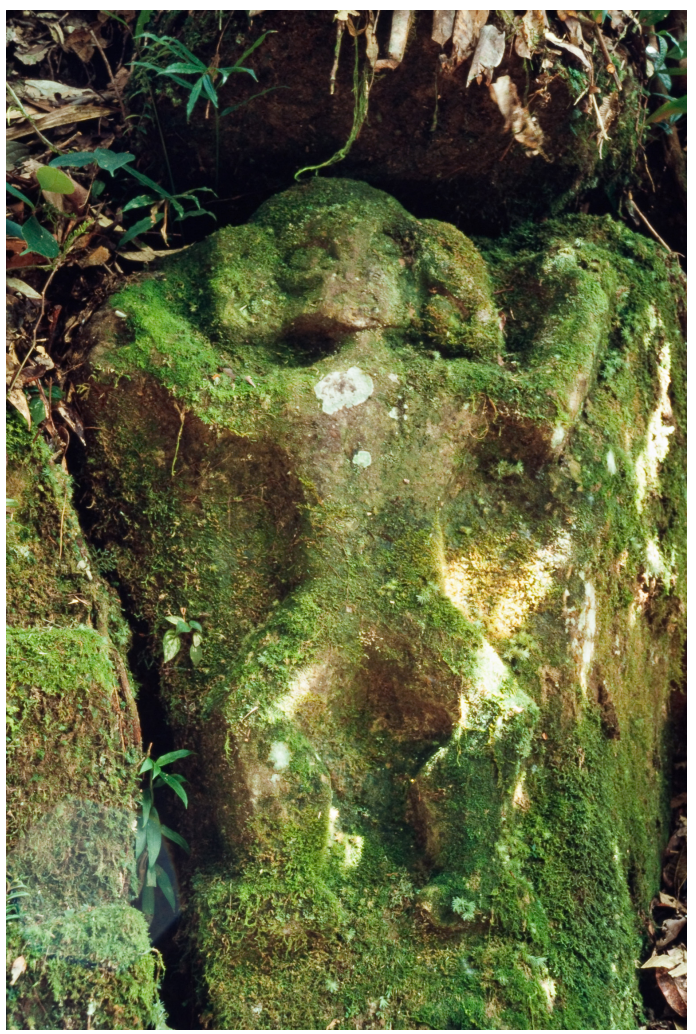

FIGURE 10

Stone carved with spread-eagled human figure, facing outwards, high in the mountains of the Kelabit Highlands, Sarawak PHOTO KAZ JANOWSKI, 1987

represent community ancestors and are placed outside the house as protectors of the village. Noble houses have particularly impressive stone images, siraha salawa, which represent founding ancestors (Feldman 1990:31-2). This differentiation between wooden house-level ancestors and stone noble/community/founding ancestors underlines the fact that the harder the substance, the greater the accumulation of vital force.

Stone is, in Southeast Asia, widely associated with the dead and the ancestors in a funerary context, as indeed it is in other parts of the world. The dead have been placed inside stone jars, as they sometimes were until the 1950s in the Kelabit Highlands in Sarawak (Barker et al. 2008) (Figure 2) and as they probably were inside the stone jars of the Plain of Jars in Laos (Colani 1935); under stone dolmens; in stone sarcophagi; and in stone tombs (Barbier 1999; Hoskins 1999; Hutton 1926). The dead may also be simply placed close to stone. In the Kelabit Highlands the dead were, until the 1950s, most often placed in wooden coffins or in ceramic 'dragon' jars near stone cists and jars said to have been placed there by ancestors — which are themselves often close to natural stone outcrops. In the Toraja highlands of South Sulawesi, the dead are placed in family burial chambers (liang) cut out of cliffs (Waterson 2009:131). Where a 
dead person is placed in association with stone, such a stone may, as we have seen, come to be seen as the abode of his or her spirit, particularly if the person is someone of significance.

One can draw the conclusion from this close association between stone and bone that, in the context of the cosmological continuum which I mentioned above between hard and soft and dry and wet, as the dead become harder and drier they are in some sense absorbed into the stone, which becomes an accumulation of vital force and a source of this for descendants via the tomb of an individual ancestor or group of ancestors. The placing of the dead is important in Austronesian societies (Bloch 1971), and in some areas stone tombs are often placed in the middle of the village, emphasizing their communal nature and the link between the living and the dead (for Sumba, see, for instance, Hoskins 1999). Among the Toraja, ancestors must traditionally be placed in stone tombs, where they are a source of life force for their descendants (Waterson 1995). Among the Batak in Sumatra, the group of ancestors, placed in a communal stone tomb (Barbier 1999), is regarded as a sourcea kind of 'pool' - of vital force for their living descendants (Chambert-Loir and Reid 2002). In some places stone cemeteries are far away from the village, as in the Kelabit Highlands, but it is interesting to note that recent excavations have shown that at least one of the megalithic cemeteries (menatoh) in the Kelabit Highlands was originally a site occupied by the living, implying perhaps that the dead may have been placed in tombs within the village itself. ${ }^{12}$

Although most of the dead seem to lose their individuality, with their names and specific places of burial forgotten, certain very prominent people are sometimes remembered by name, with their place of burial marked by a stone. In Eastern Indonesian communities, the stone graves of key ancestors are regarded as the fount of vital force for all of those who regard themselves as their descendants. More recent important ancestors may also be remembered, with stone or cement graves built adjacent to the houses of the living. However, the person who is said to be buried in such an individual tomb is generally mythical or semi-mythical — an apical ancestor or culture hero. An example is the tomb of the culture hero Monsopiad in Sabah (Phelan 1997:83-5). A figure like Monsopiad represents the origins of a group of people as a whole rather than being a straightforward historical individual. Tombs are closely associated with mythical or real founding ancestors, from whom kin groups or whole villages trace their ancestry. Villages which contain ancestral tombs often come 
to be seen as ancestral villages, and tombs situated there are used for the dead of other villages too, who are regarded as descendants of those ancestors-as is the case in Sumba (Hoskins 1999).

In coastal areas, where there are small states that are now Muslim, there are a number of megalithic sites said to be the graves of Muslim 'saints' or of princes or princesses. Such sites are described in Malay as keramat (a term derived from Arabic, referring to the supernatural wonders performed by Muslim saints; see Winstedt 1977). Visits to these places are made to access vital force. The custom in Java of making pilgrimages to the graves of 'saints', who are identified with ancestors, is an example of this (see Fox 1991; Chambert-Loir 2002). With the development of more centralized societies and the adoption of Islam, the association between a tomb and a specific ancestor may have grown more prominent, and it is likely that originally individuals were not remembered, at least in some parts of the region (Miksic 2004:192).

The term keramat, used to describe the stone graves of Muslim 'saints', is also used to refer to natural stones in the landscape that are regarded as accumulations of vital force (Figure 5) (Sellato 2002:11), and the term as it is used in modern Indonesia and Malaysia can be translated as 'powerful'. This points to an overlap, and possibly a conflation, of beliefs about ancestors and beliefs about spirits of the land, which links ancestral origins to the land itself. This is, in turn, linked to beliefs about the cosmologically and socially significant coming together, within Austronesian societies, of groups regarded as autochthons and what have been described as 'stranger-kings' (Sahlins 1985; Sahlins 2008:192). It is interesting to note that there are indications that a conflation of ancestors with the land is a belief that is shared with the Chinese in Southeast Asia. In Singkawang in Kalimantan there are numerous Chinese shrines to what are known as datuk or latuk, a term which means 'grandparent' in Malay/Indonesian. These appear to be conflations of Chinese human ancestors, Chinese land spirits brought from the homeland long ago, local ancestors, and spirits of the land (Chai 2018). Many of these shrines are shared with local tribal people.

\section{Stone, Gender and Reproduction}

In myths about the coming together of 'stranger-kings' and autochthons, the autochthonous group tends to be overtly or implicitly associated with the female principle and the incoming 'king' with the male principle, something which is sometimes expressed in diarchic rule with a male and a female aspect. The coming together of male and female is fundamental to the transmission of 
vital force in Southeast Asia. It is also expressed in myths about ultimate origin, many of which tell of an ungendered origin deity which split into male and female, bringing the cosmos into being (see, for example, Atkinson 1989; McKinnon 1991:42-3).

Thus, it is not surprising that there is a gendered aspect to stones. In Borneo gendered stones are often said to reproduce, generating more stones..$^{13}$ The story related by Perry (citing Kruyt 1906) about the Minahasa people originating as the result of friction between two stones also implies gendered stones (Perry 1918:78-9). In Polynesia there are origin myths telling of male and female stones, sometimes giving birth to gods and sometimes to humans. In Tikopia there are two stones at opposite sides of the island, one male and one female, which are said to have given birth to the island and its inhabitants (Williamson 2013 [1933]:18). The Toraja of Sulawesi relate in myth how the first women-as well as the first pig — emerged from stones (Waterson 2009:129).

Where stones are gendered, they often come in closely associated pairs or couples. Sometimes the male stone is taller and the female shorter (Figure 11); sometimes the male stone is upright and the female recumbent; sometimes, as in places in Flores and Sumba, a male wooden post is associated with a female recumbent stone (Hoskins 1999; Lewis 1988:94, 102). Among the Ngada people in Flores, offerings are made to male and female apical ancestors on paired stones (Figure 7). This pairing of male and female echoes the Hindu lingga-yoni relationship. In some of the areas which have been Hindu, such as Cambodia, Vietnam, and Java, this lingga-yoni symbolism is explicit (see Figure 12). However, upright male and recumbent female stones are also present in areas such as Nias and West Flores (Lewis 1988:211), places where there has not been any history of direct Hindu influence. Van der Hoop argues that there are many indications in Southeast Asia of a pre-Hindu fertility cult, expressed through upright male and recumbent female stones (Van der Hoop 1932:2009 seq.). In Southeast Asia, the association between female and earth/water on the one hand and male and sky on the other, which appears to be expressed in the uprightness of 'male' stones and the recumbent nature of 'female' stones, is deep-rooted and likely to predate Hinduism.

The importance of the complementarity of male and female is sometimes expressed in the stone itself, which is presented as in some sense containing within itself both male and female. In Sumba, where stones brought from quarries along the coast for tombs are treated initially as young brides, that is, as female, they are later treated as brave warriors, that is, as male; and when a

13 Barbier 1999:107; Hose and McDougall 1912:16; Hutton 1926:79; Janowski and Barton 2012. 


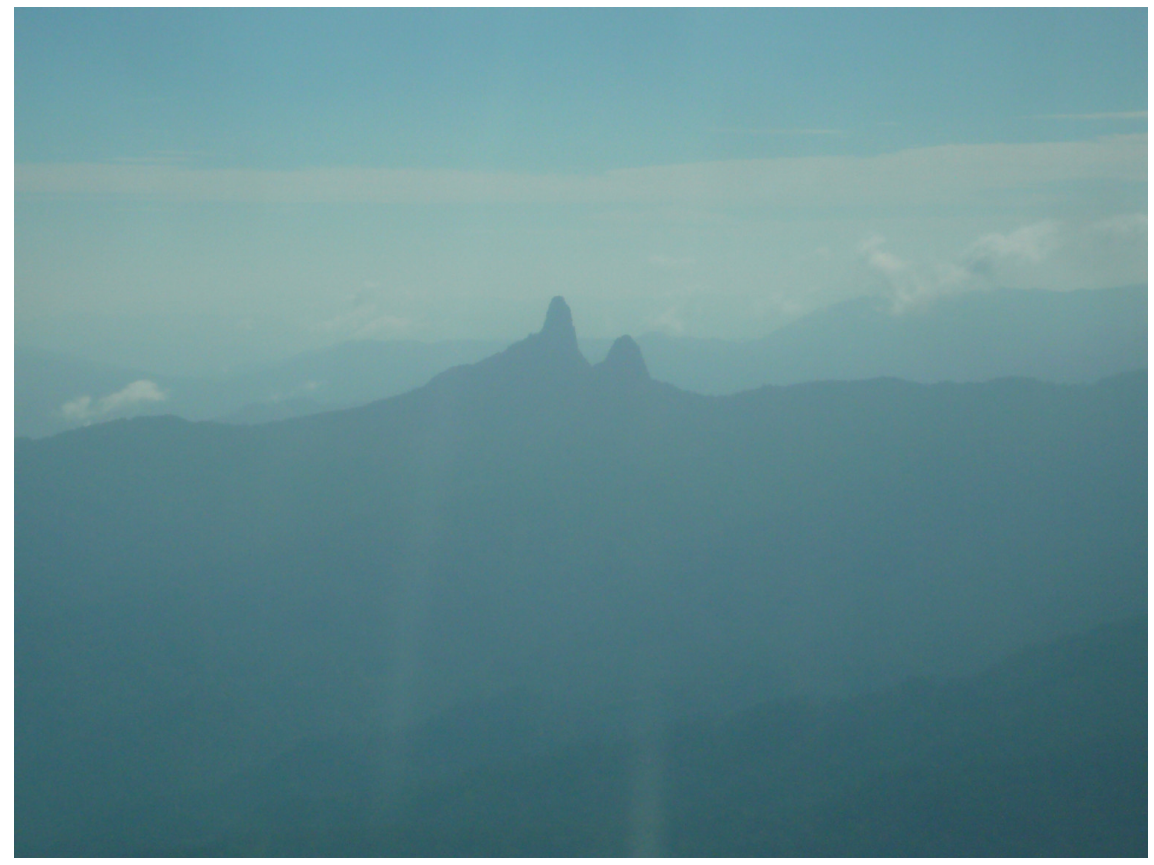

FIGURE 11 Batu Lawi mountain in the Kelabit Highlands, Sarawak, said in myth to be a male and female couple who originally moved around the landscape before settling where they are now

PHOTO BY AUTHOR, 2011

stone (now cement) tomb is completed, the capping stone is considered male and the cavity female (Hoskins 1999:173-4). In Nias, adu ancestral stones are often hermaphroditic (Feldman 1990:30).

The flow of vital force usually slows down gradually, eventually leading to petrification. This occurs with age, and death is a significant point in the process of petrification-although not the end of the process. At the point of death of an individual human, individual sentience is, except in the case of prominent leaders, often subsumed within the sentience of the ancestral group, which the spirit of the dead joins. The process is not immediate, however, and the spirits of the dead may be reluctant to go along with this transition and need encouragement, which is given through funerary rituals. This appears to be the basis for the practice of secondary disposal of the dead (Hertz 196o), which is fairly common in the region (see, for instance, Barbier 1999:86; Janowski and Barton 


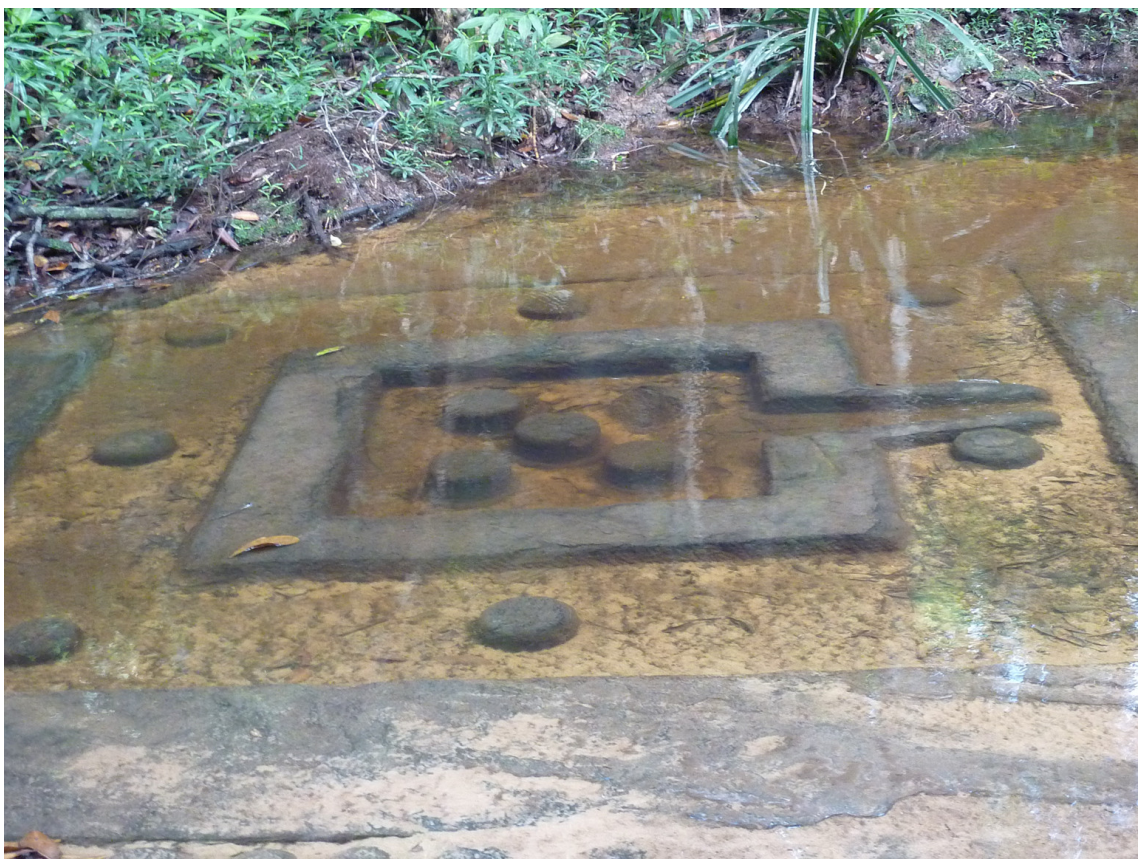

FIGURE 12 Submerged yoni with five lingga at Kbal Spean, Cambodia PHOTO BY ANANDAJOTI, NO YEAR. HTTPS://COMMONS.WIKIMEDIA.ORG/ WIKI/FILE:KBAL_SPEAN_-_010_SUBMERGED_YONI_WITH_FIVE_LINGGAS _(8584740030).JPG

2012). This moves the spirits along the process and eventually confirms what is, in effect, the dispersal of their individual spirit within the community of ancestral spirits. Indeed, it is important that the process be gradual; when a person dies suddenly—such as through violence or in childbirth—that person's spirit will be dangerous and will thus be feared by the living.

While the vital force of those who die usually turns to stone slowly as they become ancestors and lose their individual identities, petrification of vital force can also happen suddenly. This can happen as a result of human misbehaviour, including laughing at animals, disrespect of elders, incest, or a failure to provide hospitality. Such misdeeds are widely believed to lead to thunderstorms, which can cause petrification. My informants in the Kelabit Highlands can point to several natural stone outcrops in the landscape which are said to have once been houses and which were turned to stone during thunderstorms triggered by their inhabitants laughing at animals. Belief in this phenomenon is widespread. Among the Temiar who live in the interior of the Malay peninsula, it is believed that if humans laugh at certain creatures - an action which is described as misik - this will result in thunderstorms, earthquakes and floods 
(Benjamin 2014:69-71). Ling Roth tells a story about an Iban man from Sembang who arrived with his young son in the village of Si Lebor. The chief of the village gave food to the man but refused to give anything to his son. Consequently, there was a huge storm and the chief's house began to melt away, until it and the people in it became molten lava. A hill with rocky precipices is supposed to be all that is left of the village (Ling Roth 1898:205-7, 306). Hose and McDougall tell of a limestone cliff on the Baram river which contains a cave known as Batu Gadang or 'Ivory Rock', which is said in Kayan legend to have been formed by a longhouse being turned to stone owing to incestuous conduct within it (Hose and McDougall 1912, cited in Perry 1918:126). The Iban of Sarawak believe that certain rocks, known as batu kudi (stones caused by the wrath of God), are the petrified remains of human beings who have been turned to stone, with the accompaniment of great thunderstorms, for laughing at animals, breaches of hospitality, and incest (Hose and McDougall 1912, cited in Perry 1918:125). In Central Sulawesi there are stones near Lake Poso which are said to be the petrified remains of a village in which the people laughed at a cat; the largest stone is the temple, the smaller stones are the houses, and the smallest stones are the rice granaries. In Minahasa there are a number of large stones in lakes which are said to be villages which have been petrified (Perry 1918:125). The Manabo of Mindanao in the Philippines tell of the occupants of a boat who passed a cliff where they saw a cat and a monkey fighting. They laughed and passed remarks, and they and the boat were turned to stone. In Mindanao, Beyer reports that it was believed to be dangerous to imitate frogs, as this could lead to thunderbolts and petrification. He relates the story of Ango, who went into the forest to hunt, where he imitated some frogs he heard. He was then followed back home by a large number of small stones, which attached themselves to him. He gradually turned to stone, together with his wife and children, who tried to help him. Ango and his family are said to be visible on the peak of Binaci (Beyer 1913:90). Van der Hoop tells the story of Lidah Pait (Bitter Tongue)/Seroenting, a powerful hero said to have lived in the region around the Pasemah plateau in Sumatra, who had great šakti (vital force/power) and is believed to have turned many people, animals, houses, and objects to stone. In some instances this is said to have been because they crossed him, but from stories told about the hero it seems that simple contact with him, especially his tongue, was believed to cause petrification (Van der Hoop 1932:5).

In the Kelabit Highlands, petrification is said to be particularly likely to occur if hail, which is described as 'stone rain' (udan batuh), falls. Hailstones are essentially believed to be 'petrified' water, and it seems that they are regarded as a terrifying instantiation of a sudden flow from one end of the water-stone 
continuum to the other. My informants in the Kelabit Highlands told me that when they were children, in the 196os and 1970s, they would be told to go out and throw hailstones off the veranda of the longhouse, to stop the process of petrification beginning. If they had not done this, the longhouse would, it was believed, have turned to stone.

Thunder and lightning are regarded throughout the region as causing stones to fall from the sky; as discussed above, stone axe heads and tools found in the forest are widely regarded in this light. In the Kelabit Highlands, I was told by one of my informants that the 'thunderstones' (batu pera'it) found and kept as amulets in the past were actually formed at the moment that the lightning hit the earth, rather than falling from the sky already formed (Janowski and Barton 2012). In other words, they resulted from a sudden flow of power along the water-stone continuum, into stone.

Suddenly petrified ancestral and culture hero figures, regardless of what led to their petrification, may be venerated and treated as sources of vital force. This is the case among the Batak, where sacrifices are made to stones that are said to be ancestors petrified due to misbehaviour (Barbier 1999:105).

Mountains are cosmologically extremely important in Southeast Asia, as they also are in Japan and China within Buddhism, Taoism and Shinto (see, for instance, Grapard 1982; Shaw 1988:91-2; Hahn 1988). In Southeast Asia, they are regarded as sacred, as a locus and source of vital force, and as the abode of spirits. They were in the past and continue to be a focus for pilgrimage, particularly on the part of leaders. When visiting the volcanic mountain of Kelimutu in Flores in March 2019, I was told that the first president of Indonesia, Sukarno, used to regularly visit the mountain to meditate, and that his son continues to visit. States in the region have also built their own mountains, in the form of large stone monuments such as Borobudur on Java and Angkor Wat in Cambodia (Figure 13), as well as the megalithic site of Gunung Padang on Java. These monuments are man-made sacred mountains — as well as, at the same time, representing mandala, that is, the entire cosmos. The highland megaliths of Sumatra are oriented towards mountains (Van der Hoop 1932:142), as is the megalithic site on Gunung Padang in West Java.

The cosmological significance of mountains is expressed in their stoniness, which represents an accumulation of vital force. Stony places on mountainsoutcrops, cliffs and caves-are regarded as the particular abodes of spirits. The Ifugao tell of a spiritual being, son of the greatest god, Wigan, who became part 


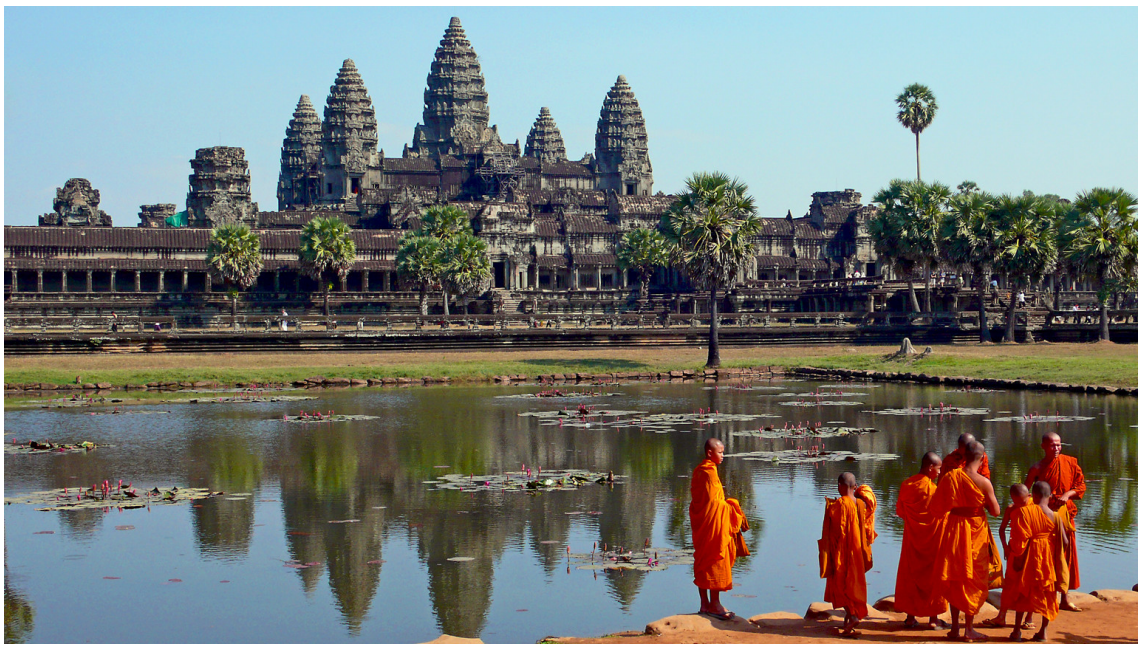

FIGURE 13 Angkor Wat, Cambodia

PHOTO BY SAM GARZA, 2006. HTTPS://COMMONS.WIKIMEDIA.ORG/WIKI/ FILE:BUDDHIST_MONKS_IN_FRONT_OF_THE_ANGKOR_WAT.JPG

of the rock of a mountain when he struck it with his spear to create a flow of water; the water is said to come out of his mouth, meaning that he is in some sense identified with the mountain (Beyer 1913:104). In East Kalimantan on the island of Borneo, there is a story about a supernatural being called Abang Gandei, who lived on Mt Susur before moving downstream to live on Mt. Siau near Modang. Even he was subject to the processes of petrification caused by laughing at an animal (see above). One day he caught an ape and clothed it, whereupon he and his followers laughed at it, and the ensuing thunderstorm turned him to stone; he can still be seen on the mountain (Barth 1897, cited in Perry 1918:126).

It seems possible that the logic of the cosmological centrality of mountains may be grounded in the fact that they are the coming-together-place of the two principles of the living cosmos: male (sky/mountain/stone) and female (earth/water). One can hypothesise that water, having flowed down the mountain, may be regarded as following a circular path, making contact with the sky, falling as rain, and flowing back down the mountain. In Borneo, the complementary relationship between hornbill and dragon (Schiller 1991; Sellato 1992) seems to express this well.

Mountains, and particularly stony places on mountains, are associated with ancestors and ancestral spirits. Their cosmological centrality, and indeed the circular path of the flow of life, is expressed in the fact that the human dead are often believed to journey, after death, to mountains. The dead are some- 
times placed within cliffs on mountains, as in the Toraja area of Sulawesi and in Borneo, or in caves in mountains and hills. Holy places and shrines in the mountains, associated with ancestors, deities, spirits, or culture heroes, are common in the region, and are venerated by noble and kingly leaders as well as tribal upland peoples.

Mountains themselves may be attributed sentience and individuality. They may not only be believed to be the abode of spirits (in the plural) but may be associated with an overarching spirit, as is the case in the Kelabit Highlands. Here there is a belief in a spirit associated with each mountain peak as well as a belief in an overarching spirit in some sense incorporating all the mountain spirits (Janowski 2014b). Mountain peaks may be gendered, as are the stone peaks of the mountain Batu Lawi, which has two peaks, one tall (male) and the other shorter (female) (Figure 11). These are regarded as a couple who originally moved across the landscape, sitting in places which can be identified due to the presence of certain kinds of vegetation, until they turned to stone and became static, turning into the mountain. ${ }^{14}$ In Polynesia, too, there are beliefs about gendered mountains (Williamson 2013 [1933]:17).

\section{$9 \quad$ Stone and Status}

Status in human society in Southeast Asia is associated with acting as a source of vital force for others. Leaders and rulers strive to demonstrate the ability to control and dispense vital force. This is often expressed through stone. As we have seen, leaders often have an individual enduring existence as stone guardians for their communities, and associate themselves with stony mountains, real or man-made. In life, too, leaders associate themselves with stone, erecting, carving, and manipulating it (see Figure 14).

This is part of a wider interest in crafting the landscape. It can be argued that humans have always manipulated and managed the natural environment and therefore 'crafted it' (see Barker and Janowski 2011 for a discussion of this in relation to Southeast Asia). In New Guinea, Polynesia, and Southeast Asia, however, the crafting of the landscape has gone beyond this; through moving stone and earth and diverting water, humans have made status-generating and status-affirming 'marks' on the landscape, as I have explored among the Kelabit (Janowski and Langub 2011). These 'marks' include feats which have practical utility, including the making of cuts on ridges to facilitate the pas-

14 According to a myth which was related to me by Balang Pelaba of Pa' Dalih. 


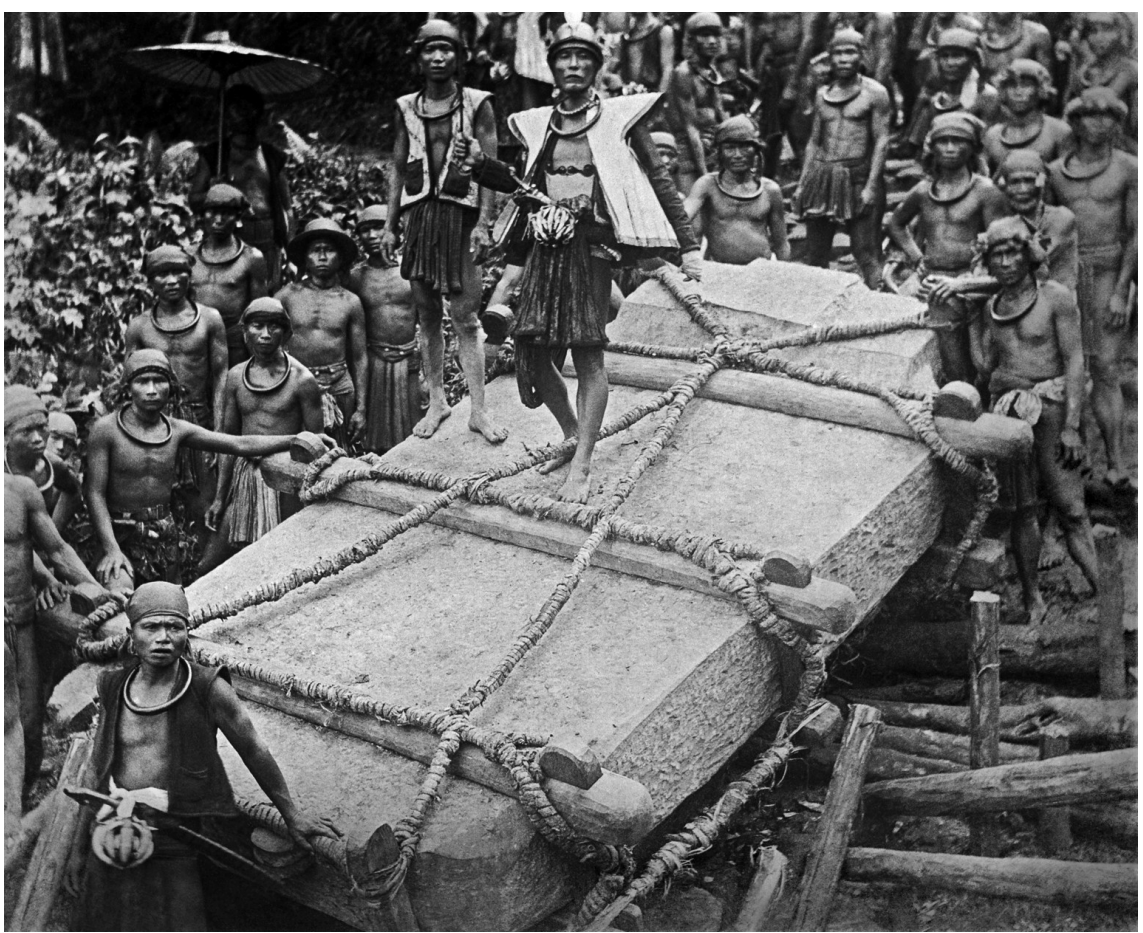

FIGURE 14 Stone erected in the village of Bawematoloeo in 1915 HTTPS://EN.WIKIPEDIA.ORG/WIKI/FILE:COLLECTIE_TROPENMUSEUM _\%27HET_VERSLEPEN_VAN_DE_STEEN_\%27DARODARO\%27_VOOR_DE _GESTORVEN_SAOENIGEHO_VAN_BAWAMATALOEA_NIAS_TMNR_1000095B .JPG

sage of paths across passes, the erection of boundary stones, the making of terraces and seats for village meetings, the creation of terraces and channels for the diversion of water for rice-and taro-growing, and the making of graves and tombs. They also include landscape manipulations that have no function other than as memorials to living or deceased leaders. These can be created through the medium of earth - for example, earthen crocodiles (Datan 2011; Sellato 1999) - but are more often constructed through the placing of large stones, ranging from guardian stones to man-made mountains such as Borobudur or Angkor Wat.

Crafting the landscape through moving stone and earth and diverting water arguably confirms and generates status because it demonstrates the ability to manipulate the flow of vital force through the landscape. The fact that landscape-crafting is often related to the practice of wet-rice agriculture is grounded in the fact that rice is a cosmologically central crop. Both tribal 
peoples and polities in the region engage in irrigation and drainage works for rice-growing, which glorifies the leader or ruler who initiates and facilitates such works.

Landscape-crafting among tribal peoples, particularly the erection of large stones, occurs at what may be described as 'feasts of merit'. The term 'merit' is used in English as a gloss for terms for vital force or cosmic power as these ideas are expressed in Southeast Asian Buddhism (Tannenbaum and Kammerer 1996). The term 'feast of merit' is used most often in relation to feasts held on the mainland, particularly among hill peoples such as the Naga, but it is also an appropriate term to describe equivalent feasts held in 'tribal' societies throughout Island Southeast Asia. Such feasts are common in the region, and have the aim of confirming and/or enhancing the status of an individual or a couple. ${ }^{15}$ They may be held either during the life of a person or in a sequence held after a person's death. If held posthumously, they may lead to the dead person coming to be regarded as an ancestral spirit, sometimes identified with the powerful naga (Barbier 1999:87).

Feasts of merit bring together large numbers of people and include not only feasting but landscape-crafting labour. The number of people who are brought together to work and be fed is an expression of the power and status of the hosts. Such feasts are highly competitive, as can be seen, for example, in Sumba (Hoskins 1986) and in Tana Toraja in South Sulawesi (Waterson 20og: Ch. 18). While not all feasts of merit involve the erection of stones, the erection of a stone is more likely at the funeral of a high-status individual. In Tana Toraja a standing stone may be erected as a memorial to the deceased at a funeral for an individual of very high status (Waterson 2009:375), and this was also the case until the 1950s among the Kelabit of Sarawak. Competition can sometimes be very fierce when the wherewithal for holding feasts increases due to an increased flow of resources, leading to an escalation in the lavishness of feasts. This is happening at the moment in the Kelabit Highlands (Janowski 2003c), as well as in Sumba (Hoskins 1986).

Feasts of merit are held within groups where status is not ascribed by birth or not wholly by birth. They are an arena within which it is possible to attain status in societies which practise what Arhem describes as hierarchical animism (K. Arhem 2016:19). Whereas in the more centralised societies of the region status passes more clearly from parent to child, grounded in a belief that levels of vital force are passed lineally in a predictable way, among hill tribes status is

15 Barbier 1999; Feldman 199o; Hoskins 1999; Hutton 1922; Janowski 2007a; Viaro and Ziegler 1999; Von Furer-Haimendorf 1939; Ziegler 1990. 
more fluid, and in each generation individuals have to demonstrate that they are the locus of concentrations of vital force. Through the ability to host feasts and the making of marks on the landscape at such feasts it becomes clear how vital force is distributed; thus, feasts can be said to be status-confirming on a theoretical level, in local thought, but status-generating in practice.

The fact that eating is central to feasts of merit is related to the significance of the sharing of a meal consisting of rice and meat from domesticated animals, as well as to the importance of being able to care for and feed their people on the part of leaders. I have argued that irau feasts among the Kelabit express the complementarity of rice (which is primarily associated with the female but also represents the coming together of male and female) and meat (which is associated with the male), and that such feasts generate a higher-level 'hearth group' which is based in the domestic group based on the hearth. Within this higherlevel hearth-group the guests are fed by the hosts, in a context where vital force is believed to be processed via gender and transmitted through the rice meal to dependants (for a discussion of this see Janowski 1995:2007a). I would suggest that this kind of analysis of such feasts may apply more widely in Southeast Asia and that feasts of merit held by tribal groups, as well as the large-scale rice meals regularly hosted by rulers of states, can perhaps be understood in this light. ${ }^{16}$

The marks on the landscape which are made at feasts of merit are most often made in stone, and this is grounded in the fact that the moving and carving of stone implies high levels of vital force. Among the Batak of Sumatra, this is expressed through the fact that only powerful datu panggana, or 'magiciancarvers', are able to carve stone - and introduce spirits into stones-because only they have sufficient levels of sahala or vital force/power (Barbier 1999:89). The carving of images of humans and powerful animals, such as the naga or the singa among the Batak (Barbier 1999:89-9o) is a particularly strong expression of the possession of high levels of vital force. With greater landscape-crafting feats, and especially the raising and carving of stone, an individual displays higher and higher levels of vital force. Feasts of merit sometimes take place in series, with an individual progressing through them and gaining in status as

16 Shared communal meals held at life-cycle events, such as the kenduri and selamatan meals in Indonesia and Malaysia, fall into a somewhat different category to feasts of merit, as they are often small-scale events and simply confirm the passage of individuals through life. However they may be used to generate status, as they are in the Kelabit Highlands, where naming feasts (irau mekaa ngadan) have taken on the role previously held by secondary funerals - now abandoned because of the adoption of Christianity—and have become highly competitive displays of status. 
the series progresses, erecting more impressive stone monuments each time (Hutton 1926; Ziegler 199o:9o-1); being able to move as big a stone as possible is associated with high levels of vital force.

Beliefs about the accumulation of vital force are profoundly entangled with patterns of social, political, and economic relations in the region (Anderson 1990; Geertz 1980; Walker 2002). The desire to accumulate vital force is closely associated with the creation of a political centre-whether this is a Javanese sultanate or a concentration of longhouses in interior Borneo-which is also a cosmological centre, consisting, as it does, of a high concentration of vital force focused on the ruler or leader.

The term 'hierarchical animism', which Kaj Arhem has suggested for the cosmologies of the 'sedentary, village-based mixed farmers' of Southeast Asia (K. Arhem 2016a:19) - a category which includes both 'tribal' peoples and peoples living within the coastal states of the region, including the Malaysarguably implies the belief that some individual humans have more vital force than others; that they are human 'hot spots' of vital force. With the concentration of vital force in certain humans and in certain objects and places comes cosmological differentiation. From a belief in cosmological differentiation comes the possibility of social differentiation. Among small-scale tribal agriculturalists this differentiation is not extreme and there is little difference in lifestyle between those of high and low status; but as societies become bigger, more complex and more centralised, cosmological and social differentiation become quite significant.

Status in Southeast Asia is closely associated with rice, on all levels-economic, political, and cosmological — and the adoption of rice-growing is associated with the growth of social, as well as cosmological, differentiation. Rice, as a crop, has had a profound effect on the social map of the region, providing a cosmological grounding for differentiation rooted in the ability to grow rice and to have good relations with the rice-spirit. It is not surprising to find, therefore, that head-hunting is closely associated with rice-growing. Despite the lively academic debate which has taken place regarding the reasons for head-hunting, there is good reason to regard it as grounded in a belief that the taking of heads brings fertility/prosperity/vital force into communities ${ }^{17}$ —vital

17 Davison and Sutlive 1991; Freeman 1979; George 1996:64-7; Hoskins 1996a, 1996b; Hutton 1928; Izikowitz 1979; Kruyt 19o6; Needham 1976. 
force which is often used to generate differentiation. The fact that head-hunting is closely associated with the growth of differentiation is expressed in the fact that it has been pursued not only by small-scale societies but also by sultanates, which are the most differentiated of societies in the region (Jakl 2016).

For Arhem, hierarchical animism contrasts with another, more egalitarian type of animism, more or less the same as Descola's (singular) category of 'animism' (Descola 2013 [2005]), among hunter-gatherer peoples in the region. Egalitarian hunter-gatherer peoples, such as the nomadic Penan in Sarawak, have been reluctant to accept rice-growing despite being placed under considerable pressure to do so from both rice-growing peoples surrounding them and the states in which they live. This rejection of rice-growing is arguably rooted in a rejection of social and cosmological differentiation and an avoidance of any significant accumulation of life force that could lead to cosmological differentiation within the human community. It is, in this context, worth noting that the Penan have never practised head-hunting, which is associated with the accumulation of vital force and the possibility of differentiation. However, the ontological and cosmological (as opposed to social and political) difference between 'hierarchical animists' and 'egalitarian animists' (to use Arhem's terms) may not be quite so significant. A people like the Penan of Borneo, who are 'egalitarian animists', do believe that vital force accumulates in hot spots; like more hierarchical peoples, they keep 'thunderstones' (batu prahit), which they see as accumulations of vital force which they can draw on for hunting (Janowski and Barton 2012). Thus, while they seem to reject social differentiation for themselves (Janowski 2016), they seem to share in a belief in the cosmological logic which underpins it.

\section{Historically Distant Ancestors and Stone}

In a number of places in the region, people actively interact with stones in the landscape that are of a kind and/or size different from any which present-day or recent humans have moved around the landscape or carved. These stones are associated with long-ago, much more powerful ancestors. In Borneo, for example, stories are told about culture heroes who were giants with much higher levels of vital force than anyone possesses now, and these ancestors could move stones around, shape them and carve them in ways that are impossible for people living now and that were, indeed, impossible for most people at that time (Phelan 1997:17; Janowski 2014/2016, forthcoming-a) (see Figure 15). The ancestors of long ago are widely regarded as having been more powerful 


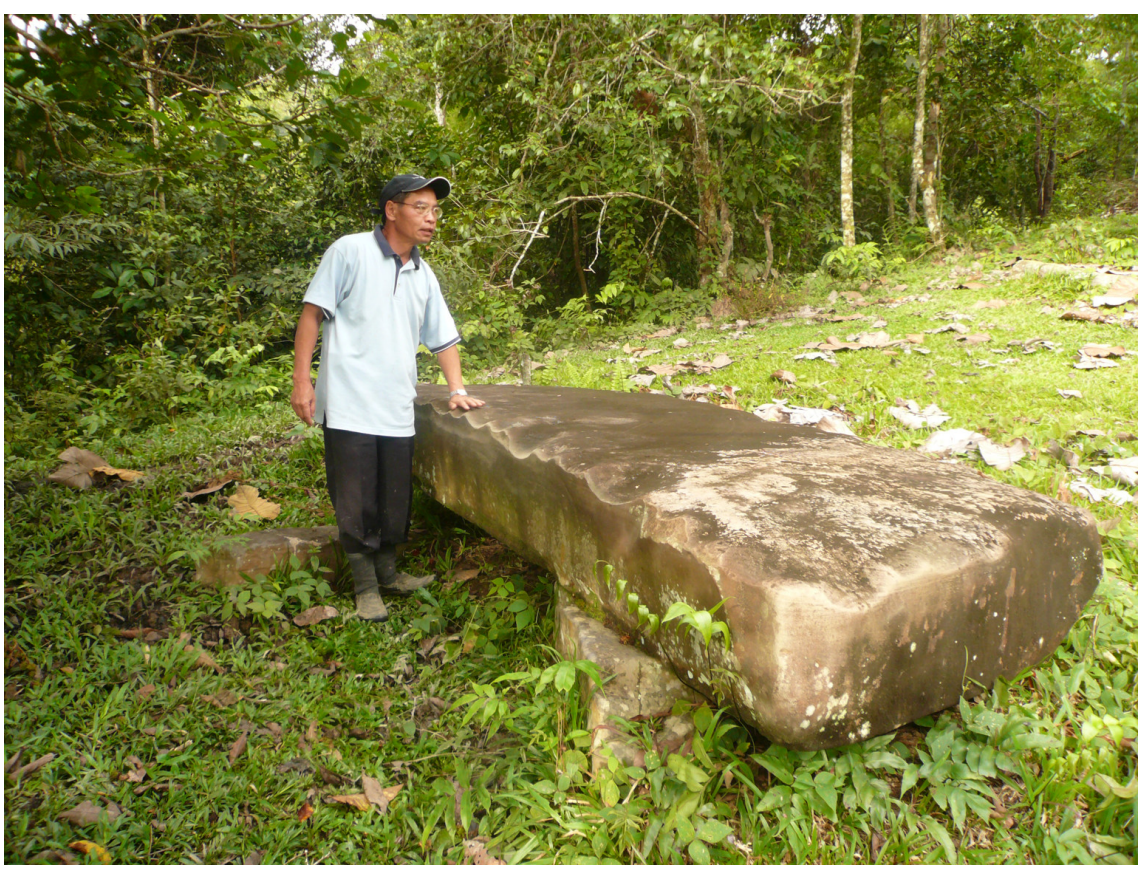

FIGURE 15 Baye Ribuh, elder from the Kelabit Highlands, Sarawak, with stone slab said to be the sharpening stone of the culture hero Tuked Rini (see Figure 1)

РнОтО BY AUTHOR, 2007

than living humans; the logic of this is that they were closer to the source of all life, to the origin of the cosmos. This is expressed in their greater ability to manipulate stone.

Stone is widely regarded as being associated with primal ancestral origins. Perry relates a story told in the Luang-Sermata group of islands about a man who brought up a stone in his net, which burst after nine months, revealing a boy. The boy married the daughter of the fisherman and they were the ancestors of the Patumera (red-stones) clan (Perry 1918:77). Perry also relates a number of origin myths that tell of humans deriving from individual stones or from the interaction between two stones, implicitly male and female, including myths from Minahasa (Perry 1918:78-9), Manipur (Perry 1918:80), and Taiwan (Perry 1918:77-8). Hodson also relates many myths from Burma and Assam that tell of the origin of humans from stone (Hodson 1911:10-14, 127, 187, 198). In Polynesia there is a widespread belief that humans originated from a stone (Williamson 2013 [1933]:16-8). There are also a number of myths stating that ancestors were made from stone by a deity or spirit. Perry relates two variants of an origin myth in which the first ancestors were made in the form of stone images. This myth was told by the people of Central Sulawesi, known in the early twenti- 
eth century as the Posso-Todjo Toraja (Perry 1918:79), and refers to myths from Borneo which state that beings of the sky-world made the first people out of stone (Perry 1918:80).

Stone in Southeast Asia is a lens allowing us to gaze into a cosmology and ontology that views the material world as made up of a flow of vital force, creating a cosmos in continuous flux. As vital force flows out of stillness and stone, from mountains and from ancestors, it becomes quick-moving, soft, and liquid; growing older, it flows more slowly and concentrates, flowing gradually, and sometimes suddenly (through petrification, triggered by thunderstorms) back to stone and stillness. In this ontology, vital force is both the driver of the cosmic dynamic and is also what is driven, meaning that it cannot be separated from the matter, the material, which expresses its presence. Such an ontology is strongly reminiscent of Deleuze and Guattari's suggestion that matter is 'always in movement, in flux, in variation' and also that 'there is a life proper to matter' (Deleuze and Guattari 2004:451-2).

Despite our realization, through modern physics, that matter is always in flux, humans do not perceive reality as a continuous mass; we are sure that it is made up of 'bits'. There has been much debate and thought around 'objects', 'things', and 'materials' in recent scholarship around material culture, which aims to explore the nature of the 'bits' of the cosmos as we humans perceive these. ${ }^{18}$ There has also been discussion of the way in which the mind bleeds beyond its boundaries so that the boundaries between the non-human and the human become unclear (Clark 2010; Clark and Chalmers 1998; Malafouris and Renfrew 2010). However, it remains the human relationship with the environment that is under consideration. This kind of approach is a form of human exceptionalism, as Ingold points out (Ingold 2012:430). An understanding of the relationship between mind and matter can usefully go beyond seeing mind as something possessed only by humans. I would suggest that the Southeast Asian ontology I have explored here is a way of thinking about the process of differentiation into 'bits' within the cosmos, the nature of such 'bits', and the way in which mind can relate to matter. For Southeast Asians, vital force is omnipresent in the cosmos; but in the course of its flow it accumulates at what I have described as 'hot spots'. These include humans who carve stone;

18 See, for example, Boivin 2008; Jones 2007; Miller 2005; Olsen 2010; Tilley 2004, 2007. 
ants who farm aphids; and the spirit within a thunderstone. In such an ontology, all material substance is in some sense enspirited and sentient, but at hot spots stronger, highly self-aware spirits come into being. Drawing on Heidegger's definition of the term 'thing' as 'a gathering of materials in movement', Ingold suggests that 'things' can include not only artefacts but humans themselves, as well as elements within the landscape (Ingold 2012:436).

The Southeast Asian ontology I have explored here suggests a mode through which things - bits' of the cosmos - may be understood as 'gathering': the accumulation of sentience - of minds, in other words-at hot spots, and the emergence of what may be described as 'spirits'. Such sentient spirits-including, but not only, humans - are regarded as able to manage and manipulate the vital force of the cosmos. The ability to do this is status-generating among rice-growers in Southeast Asia (Barker and Janowski 2011; Janowski 2016), and great efforts are put into landscape-crafting, particularly the moving and carving of stone, to demonstrate high levels of vital force and the ability to manipulate it within the landscape.

In interacting with the landscape, humans in Southeast Asia see themselves as interacting with other minds that are also in the process of managing and manipulating the flow of vital force-those spirits that express the accumulation of both matter and mind at other hot spots, equivalent to human hot spots, within the cosmos. Thus the legend of Tuked Rini, from which I quoted at the beginning of this article, relates his interactions with many non-human sentient hot spots around the cosmos, including his encounter, central to the legend, with the Hugely Tall and Powerful Spirit Tiger Rock. This mysterious entity, a sentient mind which is also a huge stone, is an icon through which we can contemplate the nature of reality for Southeast Asians. Perhaps we might also see it as an icon through which to contemplate what we may even learn from such animistic ontologies-about the nature of the 'bits' into which we cut up the cosmos, the flow which joins them, and our own actions as humans in manipulating both the 'bits' and the flow.

\section{References}

Allerton, C. (2009). 'Introduction: Spiritual landscapes of Southeast Asia', Anthropological Forum 19-3:235-51.

Anderson, B. (1972). 'Power', in: C. Holt (ed.), Culture and politics in Indonesia, pp. 1-69. Ithaca, NY: Cornell University Press.

Anderson, B. (1990). Language and power: Exploring political cultures in Indonesia. Ithaca, NY: Cornell University Press. 
Arhem, K. (2016a). 'Southeast Asian animism in context', in: K. Arhem and G. Sprenger (eds), Animism in Southeast Asia, pp. 3-3o. London and New York: Routledge.

Arhem, K. (2016b). 'Southeast Asian animism: A dialogue with Amerindian perspectivism', in: K. Arhem and G. Sprenger (eds), Animism in Southeast Asia, pp. 279-301. London and New York: Routledge.

Arhem, N. (2016). 'Wrestling with spirits, escaping the state', in: K. Arhem and G. Sprenger (eds), Animism in Southeast Asia, pp. 114-37. London and New York: Routledge.

Atkinson, J. (1989). The art and politics of Wana shamanship. Berkeley: University of California Press.

Barbier, J.-P. (1999). 'Batak monuments. In the shade of the petrified ancestors', in: J.P. Barbier (ed.), Messages in stone. Statues and sculptures from tribal Indonesia in the collections of the Barbier-Mueller Museum, pp. 79-155. Milan: Barbier-Mueller Museum and Skira.

Barker, G., H. Barton, E. Boutsikas, D. Britton, B. Davenport, E. Ewart et al (2009). 'The Cultured Rainforest Project: The second (2008) field season', Sarawak Museum Journal 66:119-84. [New Series 87.]

Barker, G., H. Barton, D. Britton, I. Datan, M. Janowski, J. Langub et al (2008). 'The Cultured Rainforest Project: The first (2007) field season', Sarawak Museum Journal 65:121-9o. [New Series 86.]

Barker, G. and M. Janowski (2011). 'Why cultivate? Anthropological and archaeological approaches to foraging-farming transitions in Southeast Asia', in: G. Barker and M. Janowski (eds), Why cultivate? Anthropological and archaeological approaches to foraging-farming transitions in Southeast Asia, pp.1-16. Cambridge: McDonald Institute.

Barth, J.P.J. (1897). De landschappen aan de Boven-Pinoh (Westerafdeeling van Borneo). Batavia: unknown publisher.

Beekman, C.D. (1973). A voyage to and from the island of Borneo. Folkestone: Dawsons. [First published 1718.]

Benjamin, G. (1979). 'Indigenous religions of the Malayan peninsula', in: A.L. Becker and A.A. Yengoyan (eds), The imagination of reality: Essays in Southeast Asian coherence systems, pp. 9-27. Norwood, NJ: Ablex.

Benjamin, G. (2014). Temiar religion 1964-2012. Enchantment, disenchantment and reenchantment in Malaysia's uplands. Singapore: Nus Press.

Beyer, H.O. (1913). 'Origin myths among the mountain people of the Philippines',

Philippine Journal of Science, 8-2:85-117.

Bloch, M. (1995). 'The resurrection of the house among the Zafiminary of Madagascar', in: J. Carsten and S. Hugh-Jones (eds), About the house: Levi-Strauss and beyond, pp. 69-83. Cambridge: Cambridge University Press.

Boivin, N. (2008). Material cultures, material minds: The impact of things on human thought, society and evolution. Cambridge: Cambridge University Press. 
Cederroth, S. (2016). 'Gods and spirits in the Wetu Telu religion of Lombok', in: K. Arhem and G. Sprenger (eds), Animism in Southeast Asia, pp. 236-56. London and New York: Routledge.

Chai, E. (2017). Of temple and tatung tradition in Singkawang. Kuching, Malaysia: UN IMAS.

Chai, E. (2018). The veneration of Dayak Latok among Chinese in Singkawang, West Kalimantan. In H.L. Chang (ed.), Transnational comparative studies on the Earth God Belief: History, ethnicity, festival and cultural heritage, pp. 297-323. Taiwan: Laureate Book Co. Ltd.

Chambert-Loir, H. (2002). 'Saints and ancestors: The cult of Muslim saints in Java', in: H. Chambert-Loir and A. Reid (eds), The potent dead. Ancestors, saints and heroes in contemporary Indonesia, pp. 132-40. Crows Nest, Australia and Honolulu: Allen and Unwin and University of Hawai'i Press.

Chambert-Loir, H. and A. Reid (eds) (2002). The potent dead. Ancestors, saints and heroes in contemporary Indonesia. Crows Nest, Australia and Honolulu: Allen and Unwin and University of Hawai'i Press.

Clark, A. (2010). Supersizing the mind: Embodiment, action and cognitive extension. Oxford: Oxford University Press.

Clark, A. and D. Chalmers (1998). 'The extended mind', Analysis 58:7-19.

Colani, M. (1935). Mégalithes du Haut-Laos (Hua Pan, Tran Ninh). Paris: e feo.

Datan, I. (2011). 'Traditional earthen crocodile effigies of the Lun Bawang in Sarawak: Functions, origin and significance', Sarawak Museum Journal 8-9o:23-42.

Davison, J. and V.H. Sutlive (1991). 'The children of Nising: Images of headhunting and male sexuality in Iban ritual and oral literature', in: V.H. Sutlive (ed.), Female and male in Borneo: Contributions and challenges to gender studies, pp. 153-230. Williamsburg: Borneo Research Council.

Deleuze, G., and F. Guattari (2004). A thousand plateaus. London: Continuum.

Descola, P. (2013 [2005]). Beyond nature and culture. Chicago: University of Chicago Press.

Domenig, G. (2014). Religion and architecture in premodern Indonesia. Studies in spatial anthropology. Leiden and Boston: Brill.

Endicott, K. (1970). An analysis of Malay magic. Singapore: Oxford University Press.

Errington, S. (1989). Meaning and power in a Southeast Asian realm. Princeton: University Press.

Feldman, J. (1990). 'Nias and its traditional sculptures', in: J. Feldman (ed.), Nias. Tribal treasures, pp. 21-44. Delft: Volkenkundig Museum Nusantara.

Fox, J.J. (1980). 'Introduction', in: J.J. Fox (ed.), The flow of life: Essays on Eastern Indonesia, pp. 1-2o. Cambridge, MA and London: Harvard University Press.

Fox, J.J. (1987). 'Southeast Asian religions: Insular cultures', in: M. Eliade (ed.), The encyclopedia of religion, Vol.13, pp.520-30. New York, NY: Macmillan Publishing Company. 
Fox, J.J. (1991). 'Visits to the tombs of the Wali, the founders of Islam on Java', in: M.C. Ricklefs (ed.), Islam in the Indonesian social context, pp. 20-38. Melbourne: Centre of se Asian Studies, Monash University.

Freeman, J.D. (1979). 'Severed heads that germinate', in: R.H. Hook (ed.), Fantasy and symbol, pp. 233-46. London and New York: Academic Press.

Furer-Haimendorf, C. von (1939). 'The megalithic culture of Assam', in: I. Evans (ed.), Forgotten kingdoms of Sumatra, pp. 215-22. Leiden: Brill.

Geertz, C. (1980). Negara. Princeton: Princeton University Press.

George, K.M. (1996). Showing signs of violence. Berkeley and Los Angeles: University of California Press.

Glover, I. and R. Ellen (1975). 'Ethnographic and archaeological aspects of a flaked stone collection from Seram, Eastern Indonesia', Asian Perspectives 18-1:51-61.

Gonthier, E. (1987). Etude des materiels lithiques des Papous Indonesiens. [PhD, Ecole des Hautes Etudes en Sciences Sociales, Paris.]

Grapard, A.G. (1982). 'Flying mountains and walkers of emptiness: Toward a definition of sacred space in Japanese religions', History of Religions 21-3:195-221.

Haddon, A.C. (1900). 'Relics of the Stone Age of Borneo', Journal of the Royal Anthropological Institute 30:71-2.

Hahn, T. (1988). 'The standard Taoist mountain and related features of religious geography', Cahiers d'Extreme Asie 4-1:145-56.

Hampton, O.W. (1999). Culture of stone: Sacred and profane uses of stone among the Dani. College Station: Texas A\&M University Press.

Hertz, R. (1960[1907]). 'A contribution to the study of the collective representation of death', in: R. Hertz, Death and the right hand. London: Cohen and West.

Hirai, N. (1960). 'The principles of shrine Shinto', Japanese Journal of Religious Studies 1-1:39-54.

Hodson, T.C. (1911). The Naga tribes of Manipur. London: McMillan and Co.

Hoop, A.N.J. Th.a.Th. van der (1932). Megalithic remains in South Sumatra. Zutphen: Thieme and Cie.

Hose, C. and W. McDougall (1912). The pagan tribes of Borneo. London: Macmillan. [Two volumes.]

Hoskins, J. (1986). 'So my name shall live: Stone-dragging and grave-building in Kodi, West Sumba', Bijdragen tot de Taal-, Land- en Volkenkunde 142:31-51.

Hoskins, J. (1996a). 'Headhunting as practice and as trope', in: J. Hoskins (ed.), Headhunting and the social imagination in Southeast Asia, pp. 1-49. Stanford: Stanford University Press.

Hoskins, J. (1996b). 'The heritage of headhunting: History, ideology, and violence on Sumba 189o-199o', in: J. Hoskins (ed.), Headhunting and the social imagination in Southeast Asia, pp. 216-48. Stanford: Stanford University Press.

Hoskins, J. (1999). 'The stony faces of death. Funeral and politics in East and West 
Sumba', in: J.-P. Barbier (ed.), Messages in stone. Statues and sculptures from tribal Indonesia in the collections of the Barbier-Mueller Museum, pp. 167-97. Milan: Barbier-Mueller Museum and Skira.

Hutton, J.H. (1922). 'Carved monoliths at Dimapur and an Angami Naga ceremony', Journal of the Royal Anthropological Institute 52:55-70.

Hutton, J.H. (1926). 'The use of stone in the Naga Hills', Journal of the Royal Anthropological Institute 5:71-9o.

Hutton, J.H. (1928). 'The significance of head-hunting in Assam', Journal of the Royal Anthropological Institute 58:329-413.

Ingold, T. (2012). 'Toward an ecology of materials', Annual Review of Anthropology 41:427-42.

Izikowitz, K.G. (1979). Lamet: Hill peasants in French Indochina. New York: AMs Press.

Jakl, J. (2016). 'The literary motif of head-taking in Old Javanese court poems (kakavin): Cěněl and varagan் terms revisited', Indonesia and the Malay World 44-129:16587 .

Janowski, M. (1984). Chieftainship among the Naga of North East India. [M. Phil dissertation, University of Cambridge.]

Janowski, M. (1995). 'The hearth-group, the conjugal couple and the symbolism of the rice meal among the Kelabit of Sarawak', in:J. Carsten and S. Hugh-Jones (eds), About the house: Lévi-Strauss and beyond, pp. 84-104. Cambridge: Cambridge University Press.

Janowski, M. (2003a). The forest: Source of life. The Kelabit of Sarawak. London and Kuching: British Museum and Sarawak Museum.

Janowski, M. (2003b). 'Masculinity, potency and pig fat: The Kelabit of Sarawak', in: H. Walker (ed.), The fat of the land, pp. 130-42. London: Footwork.

Janowski, M. (2003c). 'Who's in charge around here? Rank, kinship and the house among the Kelabit of Sarawak', in: S. Sparkes and S. Howell (eds), The house in South East Asia - a changing social, economic and political domain, pp. 95-113. London: Routledge Curzon.

Janowski, M. (2007a). 'Being "big”, being “good": Feeding, kinship, potency and status among the Kelabit of Sarawak', in: M. Janowski and F. Kerlogue (eds), Kinship and food in Southeast Asia, pp. 93-120. Copenhagen: NIAs Press.

Janowski, M. (2007b). 'Introduction. Feeding the right food: The flow of life and the construction of kinship in Southeast Asia', in: M. Janowski and F. Kerlogue (eds), Kinship and food in Southeast Asia, pp. 1-23. Copenhagen: NIAS Press.

Janowski, M. (2012). 'Imagining the forces of life and the cosmos in the Kelabit Highlands, Sarawak', in: T. Ingold and M. Janowski (eds), Imagining landscapes, past, present and future, pp. 143-64. London: Ashgate.

Janowski, M. (2014a). 'Pigs and people in the Kelabit Highlands', Indonesia and the Malay World 42-122:88-112. 
Janowski, M. (2014b). 'Puntumid: Great spirit of the heart of Borneo', Indonesia and the Malay World 42-122:120-2.

Janowski, M. (2014). Tuked Rini, cosmic traveller. Life and legend in the heart of Borneo. Copenhagen and Kuching: NIAs Press and Sarawak Museum. [Hardback 2016.]

Janowski, M. (2016). 'The dynamics of the cosmic conversation: Beliefs about spirits among the Kelabit and Penan of the upper Baram river, Sarawak', in: K. Arhem and G. Sprenger (eds), Animism in South East Asia, pp. 181-204. Oxford and New York: Routledge.

Janowski, M. (2018). 'The shape of water: The Great Spirit manifests as a dragon'. [Paper presented at the Borneo Research Council conference, Kuching.]

Janowski, M. (forthcoming-a). 'Journeys in quest of lalud (cosmic power): Highland heroes in Borneo', in: J.J. Fox (ed.), Austronesian paths and journeys. Canberra: ANU.

Janowski, M. (forthcoming-b). 'Protective power: The nabau or water dragon among the Iban of Sarawak', Sarawak Museum Journal.

Janowski, M. and H. Barton (2012). 'Reading human activity in the landscape: Stone and thunderstones in the Kelabit Highlands', Indonesia and the Malay World 40-118:35471.

Janowski, M. and F. Kerlogue (eds) (2007). Food and kinship in Southeast Asia. Copenhagen: NIAs Press.

Janowski, M. and J. Langub (2011). 'Footprints and marks in the forest: The Penan and the Kelabit of Borneo', in: G. Barker and M. Janowski (eds), Why cultivate? Anthropological and archaeological approaches to foraging-farming transitions in Southeast Asia, pp. 121-32. Cambridge: McDonald Institute, University of Cambridge.

Jenks, A. (1911). The Bontoc Igorot. Manila: Bureau of Public Printing.

Jones, A. (2007). Memory and material culture. Cambridge: Cambridge University Press. Josselin de Jong, J.P.B. de (1980). 'The concept of the field of ethnological study', in: J.J. Fox (ed.), The flow of life: Essays on Eastern Indonesia, pp. 317-26. Cambridge, MA and London: Harvard University Press.

Josselin de Jong, J.P.B. de (ed.) (1984). Unity in diversity: Indonesia as a field of anthropological study. Dordrecht and Cinnaminson: Foris.

Kirsch, T. (1973). Feasting and social oscillation: A working paper on religion and society in upland Southeast Asia. Ithaca: Cornell University Southeast Asia Program. [Data Paper 52.]

Kruyt, A.C. (1906). Het animisme van den Indische archipel. 's-Gravenhage: Nijhoff.

Laderman, C. (1991). Taming the wind of desire: Psychology, medicine and aesthetics in Malay shamanistic performance. Berkeley: University of California Press.

Lévi-Strauss, C. (1973 [1962]). Totemism. Penguin Books.

Lewis, E.D. (1988). People of the source. The social and ceremonial order of Tana Wai Brama on Flores. Dordrecht-Holland/Providence-USA: Foris [Verhandelingen 135.] 
Ling Roth, H. (1898). The natives of Sarawak and British North Borneo. London: Truslove and Hanson.

Lloyd-Smith, L., G. Barker, H. Barton, E. Boutsikas, D. Britton, I. Datan, et al (2013). 'The Cultured Rainforest Project. Preliminary archaeological results from the first two field-seasons (2007, 2008)', in: M. Klokke and V. Degroot (eds), Unearthing Southeast Asia's past. Selected papers from the International Conference of European Association of Southeast Asian Archaeologists, Vol. 1, pp. 34-51. Singapore: National University of Singapore Press.

Lloyd-Smith, L., G. Barker, H. Barton, I. Datan, C. Gosden, B. Nyiri, et al (2010). 'The Cultured Rainforest Project: Archaeological investigations in the third (2009) season of fieldwork in the Kelabit Highlands of Sarawak', Sarawak Museum Journal 67:57-104. [New Series 88.]

Malafouris, L. and C. Renfrew (eds) (2010). The cognitive life of things: Recasting the boundaries of the mind. Cambridge: Mcdonald Institute of Archaeological Research.

McKinnon, S. (1991). From a shattered sun. Hierarchy, gender and alliance in the Tanimbar Islands. Madison: University of Wisconsin Press.

Miksic, J. (2004). 'From megaliths to tombstones: The transition from prehistory to the early Islamic period in highland West Sumatra', Indonesia and the Malay World $3^{2-}$ 93:191-210.

Miller, D. (2005). 'Materiality: An introduction', in: D. Miller (ed.), Materiality, pp. 1-5o. Durham, NC: Duke University Press.

Mills, J.P. (1926). The Ao Nagas. London: Macmillan.

Mus, P. (1933). 'Cultes indiens et indigènes au Champa', Bulletin de l'Ecole Française d'Extrême-Orient 33:367-410.

Needham, R. (1976). 'Skulls and causality', Man 11:71-88.

Ngaosrivathana, M. and P. (2009). The enduring sacred landscape of the Naga. Bangkok: Mekong Press.

Okushima, M. (2014). 'Stone adzes as "thunder god teeth" among the Kayanic peoples of East Kalimantan: A preliminary report', Borneo Research Bulletin 45:299-306.

Olsen, B. (2010). In defence of things. Archaeology and the ontology of objects. Lanham, MD: Altamira Press.

Perry, W.J. (1918). The megalithic culture of Indonesia. Manchester: Manchester University Press.

Phelan, P.R. (1997). Traditional stone and wood monuments of Sabah. Kota Kinabalu: Centre for Borneo Studies.

Playfair, A. (1909). The Garos. London: David Nutt.

Sahlins, M. (1985). Islands of history. Chicago: University of Chicago Press.

Sahlins, M. (2008). 'The stranger-king, or elementary forms of the politics of life', Indonesia and the Malay World 36-105:177-99. 
Schiller, A. (1991). 'On "the watersnake which is also a hornbill": Male and female in Ngaju Dayak mortuary symbology', in: V.H. Sutlive (ed.), Female and male in Borneo. Contributions and challenges to gender studies. Williamsburg: Borneo Research Council.

Sellato, B. (1992). Hornbill and dragon. Singapore: Sun Tree Publishing.

Sellato, B. (1999). 'Megalithic monuments of the Kerayan district (East Kalimantan)', Borneo. People and plants 5-2:20-3.

Sellato, B. (2002). 'Castrated dead: The making of un-ancestors among the Aoheng, and some considerations on death and ancestors in Borneo', in: H. Chambert-Loir and A. Reid (eds), The potent dead. Ancestors, saints and heroes in contemporary Indonesia, pp. 1-16. Crows Nest, Australia and Honolulu: Allen and Unwin and University of Hawai'i Press.

Shaw, M. (1988). 'Buddhist and Taoist influences on Chinese landscape painting', Journal of the History of Ideas 49-2:183-206.

Sillander, K. (2016). 'Relatedness and alterity in Bentian human-spirit relations', in: K. Arhem and G. Sprenger (eds), Animism in Southeast Asia, pp. 157-8o. London and New York: Routledge.

Skeat, W.W., and Blagden, C.O. (1900). Malay magic: Being an introduction to the folklore and popular religion of the Malay pensinsula. London: Macmillan.

Sprenger, G. and K. Arhem (eds) (2016). Animism in Southeast Asia. London and New York: Routledge.

Stuart-Fox, M. and S. Misai (2010). Festivals of Laos. Bangkok: Silkworm Books.

Tannenbaum, N. and C.A. Kammerer (eds) (1996). Merit and blessing in mainland Southeast Asia in comparative perspective. New Haven: Yale University Press.

Tannenbaum, N. and C.A. Kammerer (eds) (2003). Founders' cults in Southeast Asia: Ancestors, polity and identity. New Haven, ст: Yale University Press.

Terwiel, B.J. (1985). 'The rotating Naga: A comparative study of an excerpt from the oldest Tai literature', ASEMI (Asie du sud-est et monde insulindien) 16-1/4:221-45.

Tilley, C. (2004). The materiality of stone. Explorations in landscape phenomenology. Oxford: Berg.

Tilley, C. (2007). 'The materiality of materials', Archaeological Dialogues 14:16-20.

Viaro, A. and A. Ziegler (1999). 'Stones of power. Statuary and megalithism in Nias', in: J.-P. Barbier (ed.), Messages in stone. Statues and sculptures from tribal Indonesia in the collections of the Barbier-Mueller Museum, pp. 35-77. Milan: Barbier-Mueller Museum and Skira.

Viveiros de Castro, E. (1998). 'Cosmological deixis and Amerindian perspectivism', Journal of the Royal Anthropological Institute 4-3:469-88.

Walker, J. (2002). Power and prowess. The origins of Brooke kingship in Sarawak. Crows Nest NSw (Australia) and Honolulu, HI (USA): Asian Studies Association of Australia in association with Allen and Unwin and University of Hawai'i Press. 
Waterson, R. (1991). The living house. An anthropology of architecture in South-East Asia. Singapore, Oxford, and New York: Oxford University Press.

Waterson, R. (1993). 'Houses and the built environment in Island South-East Asia: Tracing some shared themes in the use of space', in: J.J. Fox (ed.), Inside Austronesian houses. Perspectives on domestic designs for living, pp. 320-35. Canberra: Department of Anthropology, Research School of Pacific Studies, Australian National University.

Waterson, R. (1995). 'Houses, graves and the limits of kinship groupings among the Sa'dan Toraja', Bijdragen tot de Taal-, Land-en Volkenkunde 151:194-217.

Waterson, R. (2003). 'The immortality of the house in Tana Toraja', in: S. Sparkes and S. Howell (eds), The house in Southeast Asia: A changing social, economic and political domain, pp. 34-52. London: RoutledgeCurzon.

Waterson, R. (2009). Paths and rivers: Sa'dan Toraja society in transformation. Leiden: KITLV Press.

Williamson, R.W. (2013 [1933]). The religious and cosmic beliefs of Central Polynesia. Cambridge: Cambridge University Press.

Winstedt, R. (1956). The Malays: A cultural history. London: Macmillan.

Winstedt, R. (1977). 'Keramat: Sacred places and persons in Malaya. A centenary volume, 1877-1977', Malayan Branch of the Royal Asiatic Society Reprint no. 4:48-68.

Ziegler, A. (1990). 'Festive areas, territories and feasts in the south of Nias', in:J. Feldman (ed.), Nias. Tribal treasures, pp. 79-106. Delft: Volkenkundig Museum Nusantara. 